\title{
Tsn1-Mediated Host Responses to ToxA from Pyrenophora tritici-repentis
}

\author{
Tika B. Adhikari, ${ }^{1}$ Jianfa Bai,, ${ }^{2}$ Steven W. Meinhardt, ${ }^{1}$ Suraj Gurung, ${ }^{1}$ Mary Myrfield,, Jaimin Patel, ${ }^{1}$ \\ Shaukat Ali, ${ }^{1}$ Neil C. Gudmestad, ${ }^{1}$ and Jack B. Rasmussen ${ }^{1}$ \\ ${ }^{1}$ Department of Plant Pathology, North Dakota State University, Department 7660, PO Box 6050, Fargo 58108, U.S.A.; \\ ${ }^{2}$ Diagnostic Medicine and Pathobiology, College of Veterinary Medicine, Kansas State University, M-207 Mosier Hall, \\ Manhattan 66506, U.S.A.
}

Submitted 20 April 2009. Accepted 19 May 2009.

The toxin sensitivity gene Tsn1 interacts with Ptr ToxA (ToxA), a host-selective toxin produced by the necrotrophic fungus Pyrenophora tritici-repentis. The molecular mechanisms associated with cell death in sensitive wheat cultivars following ToxA application are not well understood. To address this question, we used the Affymetrix GeneChip Wheat Genome Array to compare gene expression in a sensitive wheat cultivar possessing the Tsn1 gene with the insensitive wheat cv. Nec103, which lacks the Tsn1 gene. This analysis was performed at early timepoints after infiltration with ToxA (e.g., 0.5 to $12 \mathrm{~h}$ postinfiltration [hpi]); at this time, ToxA is known to internalize into mesophyll cells without visible cell death symptoms. Gene expression also was monitored at later timepoints ( 24 to $48 \mathrm{hpi}$ ), when ToxA causes extensive damage in cellular compartments and visible cell death. At both early and late timepoints, numerous defense-related genes were induced (2- to 197 fold increases) and included genes involved in the phenylpropanoid pathway, lignification, and the production of reactive oxygen species (ROS). Furthermore, a subset of host genes functioning in signal transduction, metabolism, and as transcription factors was induced as a consequence of the Tsn1-ToxA interaction. Nine genes known to be involved in the host defense response and signaling pathways were selected for analysis by quantitative real-time polymerase chain reaction, and the expression profiles of these genes confirmed the results obtained in microarray experiments. Histochemical analyses of a sensitive wheat cultivar showed that $\mathrm{H}_{2} \mathrm{O}_{2}$ was present in leaves undergoing cell death, indicating that ROS signaling is a major event involved in ToxA-mediated cell death. The results suggest that recognition of ToxA via $T s n 1$ triggers transcriptional reprogramming events similar to those reported for avirulence-resistance gene interactions, and that host-derived genes play an important role in the modulation of susceptibility to $P$. tritici-repentis.

Tan spot, caused by Pyrenophora tritici-repentis (anamorph: Drechslera tritici-repentis (Died) Shoemaker), is a devastating disease in wheat (Triticum aestivum L.). When P. tritici-repentis infects susceptible wheat lines, necrotic or chlorotic symp-

Corresponding author: T. B. Adhikari; Telephone: 701-231-7079; Fax: 701-231-7851; E-mail address: tika.adhikari@ndsu.edu

* The $e$-Xtra logo stands for "electronic extra" and indicates that five supplementary tables are published online. toms are induced due to the production of host-selective toxins (Lamari and Bernier 1989; Strelkov et al. 1999; Tomàs et al. 1990; Tuori et al. 1995). Eight pathogenic races of $P$. triticirepentis have been reported based on their interaction with a set of differential wheat cultivars (Lamari and Bernier 1989; Strelkov and Lamari 2003). Race 1 of $P$. tritici-repentis is predominant worldwide (Adhikari et al. 2008) and produces both Ptr ToxA and Ptr ToxC (Ciuffetti and Tuori 1999; Effertz et al. 2002; Strelkov and Lamari 2003; Zhang et al. 1997).

Ptr ToxA (ToxA) (Ciuffetti et al. 1998) is a 13.2-kDa protein (Ballance et al. 1996; Ciuffetti et al. 1997) that induces cell death in sensitive wheat cultivars (Kwon et al. 1998; Manning et al. 2004; Meinhardt et al. 2002). It has been suggested that $P$. tritici-repentis acquired the ToxA gene from Stagonospora nodorum (Friesen et al. 2006), which causes leaf blotch in wheat. In wheat tissue exposed to ToxA, rapid damage to the plasmalemma was detected by transmission electron microscopy (Freeman et al. 1995), and exposure to ToxA for $\geq 4 \mathrm{~h}$ enhanced electrolyte leakage in a sensitive wheat cultivar (Kwon et al. 1998). Recent studies indicate that ToxA shares similarity with the mammalian protein vitronectin (Manning et al. 2004; Suzuki et al. 1985). Furthermore, the vitronectin-like sequence of ToxA (Manning et al. 2004) contains a three amino acid arginyl-glycyl-aspartic (RGD) cell-attachment motif that is necessary for toxininduced cell death in sensitive wheat (Manning et al. 2004; Meinhardt et al. 2002). ToxA is internalized into the mesophyll cells and localizes to the chloroplast of sensitive but not resistant lines of wheat (Manning and Ciuffetti 2005; Manning et al. 2008). In addition, ToxA interacts with a chloroplast protein, designated ToxA-binding protein 1 (ToxABP1), suggesting that the chloroplast is a possible target for ToxA (Manning and Ciuffeti 2007; Sarma et al. 2005). Pharmacological investigations indicated that calcium signaling and protein phosphorylation were necessary for ToxA action (Meinhardt et al. 2002; Rasmussen et al. 2004). Sensitivity to ToxA is controlled by a single locus designated Tsnl on chromosome 5BL in wheat (Anderson et al. 1999; Faris et al. 1996; Lamari and Bernier 1989). Map-based cloning of Tsn1 is in progress, and one of the candidate genes encodes a nucleotide-binding site with a leucine-rich repeat (NBS-LRR) protein (Faris et al. 2008). The interaction between Tsnl in wheat (Anderson et al. 1999; Faris et al. 1996; Lamari and Bernier 1989) and ToxA in the fungus (Ciuffetti et al. 1997) follows an inverse gene-for-gene model (Lamari et al. 2002; Wolpert et al. 2002).

Gene expression studies have significantly advanced our understanding of the host defense responses that occur in plant- 
pathogen interactions. Microarray analysis has provided global gene expression profiling and identified genes of interest in both compatible and incompatible plant-pathogen interactions. The Affymetrix GeneChip Wheat Genome Array has been used to monitor gene expression profiling during the infection of wheat by Puccinia triticina (Bolton et al. 2008; Hulbert et al. 2007) and P. striiformis (Coram et al. 2007). Although knowledge of the genetics of resistance and molecular mapping has progressed by the identification and characterization of ToxA (Tomás et al. 1990; Tuori et al. 1995; Zhang et al. 1997), information regarding the molecular processes altered during the Tsn1-ToxA interaction is limited.

In a classical gene-for-gene model (Flor 1971), resistance $(R)$ genes directly or indirectly interact with pathogen effectors (avirulence $[A v r]$ genes) (Abramovitch et al. 2006; HammondKosack and Jones 1996; Martin et al. 2003). Activation of defense responses in $R$-gene-mediated resistance is coordinated by transcriptional reprogramming (Eulgem 2005). Such defense responses include a localized form of plant programmed cell death (PCD), changes in plasma membrane integrity (e.g., influx of cellular $\mathrm{Ca}^{2+}$ and $\mathrm{H}^{+}$and efflux of $\mathrm{K}^{+}$and $\mathrm{Cl}^{-}$), production of reactive oxygen species (ROS), alternation of gene expression, and activation of mitogen-activated protein kinases (MAPK) (Abramovitch et al. 2006; Lamb and Dixon 1997; Martin et al. 2003). We hypothesize that recognition of ToxA via $T s n 1$ may activate important genes involved in both the host defense response and signaling pathways. This hypothesis was addressed in the present study by using the Affymetrix GeneChip Wheat Genome Array to investigate cellular and molecular processes elicited in response to ToxA in the sensitive wheat cv. Kulm (with $T s n 1$ ) and in the insensitive wheat cv. Nec103 (without Tsn1). To confirm the transcriptome results, quantitative real-time polymerase chain reaction (qPCR) was used to compare the expression patterns of selected defense response and signal transduction genes in the compatible Tsn1-ToxA interaction. In addition, histochemical procedures were performed to detect cell death and $\mathrm{H}_{2} \mathrm{O}_{2}$ production in ToxA-sensitive and -insensitive wheat. To our knowledge, this study is the first to use global gene expression profiling to examine $T s n 1$-mediated host responses to ToxA.

\section{RESULTS}

\section{Induction of cell death in sensitive wheat in response to ToxA.}

A visible water-soaked region was observed in the leaves of the sensitive wheat cv. Kulm exposed to ToxA at $12 \mathrm{~h}$ postinfiltration (hpi) (data not shown). Symptoms expanded within the ToxA-infiltrated areas, and cell death was clearly visible by 48 hpi (Fig. 1A). In contrast, no cell death was observed in the insensitive wheat cv. Nec103, even at $48 \mathrm{hpi}$ (Fig. 1B). As expected, plants inoculated with water (mock

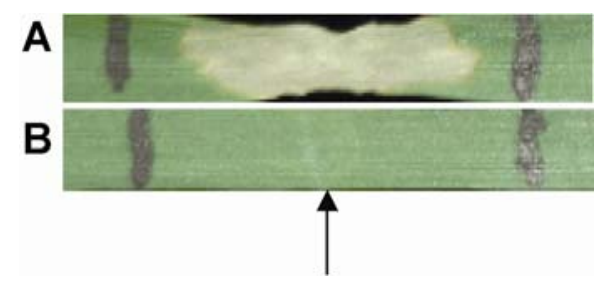

Fig. 1. Phenotype of ToxA-sensitive and -insensitive wheat cultivars. A, Cell death induced by ToxA in the sensitive wheat cv. Kulm (with Tsn1) and B, absence of cell death in the ToxA-insensitive wheat cv. Nec103 (without $T s n 1$ ); an arrow indicates where the toxin was infiltrated. Two-week-old seedlings were infiltrated with ToxA $(10 \mu \mathrm{g} / \mathrm{ml})$ from Pyrenophora triticirepentis and photographed at $48 \mathrm{~h}$ postinfiltration. inoculated) showed no cell death at any of the timepoints (data not shown).

\section{Identification and classification \\ of differentially expressed genes in sensitive wheat in response to ToxA.}

To identify significantly expressed genes during the Tsn1ToxA interaction, we used two selection criteria: i) genes considered biologically significant had to exhibit at least a twofold change in expression, and ii) the probability $(P)$ value had to be $\leq 0.05$ for specific pairwise comparison of treatments. Using these criteria, we predicted a false detection rate $<1 \%$ for each timepoint. At $0.5 \mathrm{~h}$ after ToxA infiltration, 178 genes were upregulated and 74 were downregulated; similarly, at 4 hpi, 304 genes were upregulated and 78 were downregulated (Fig. 2). At 12 hpi, the ratio changed, with 238 genes induced and 433 genes repressed. At 24 hpi, 385 genes were upregulated and 6 genes were downregulated; and, at $48 \mathrm{hpi}, 1,101$ genes were upregulated and 78 were downregulated (Fig. 2).

Cluster analysis showed two patterns of differentially expressed genes (Fig. 3). Those genes with significantly altered mitochondrial (m)RNA levels from 0.5 to 12 hpi were categorized as early-response genes (Fig. 3A, B, and C), whereas those genes induced between 24 and 48 hpi were considered late-response genes (Fig. 3D and E). To identify Tsn1-mediated molecular responses to ToxA, we used the Munich Information Center for Protein Sequences Gene Ontology (MIPS GO) descriptions (MIPS Arabidopsis thaliana database) to annotate proteins encoded by differentially expressed genes and classified these into $16 \mathrm{GO}$ biological processes (Fig. 4). At all timepoints, approximately $60 \%$ of the up- and down-regulated genes had unknown functions. Nearly $17 \%$ of the genes were annotated as transcribing proteins with unknown function. Mean overall timepoints in the categories of plant defense response, metabolism, energy, and signal transduction were 5.6, $5.3,3.0$, and $2.3 \%$, respectively (Fig. 4). The remaining categories were poorly represented.

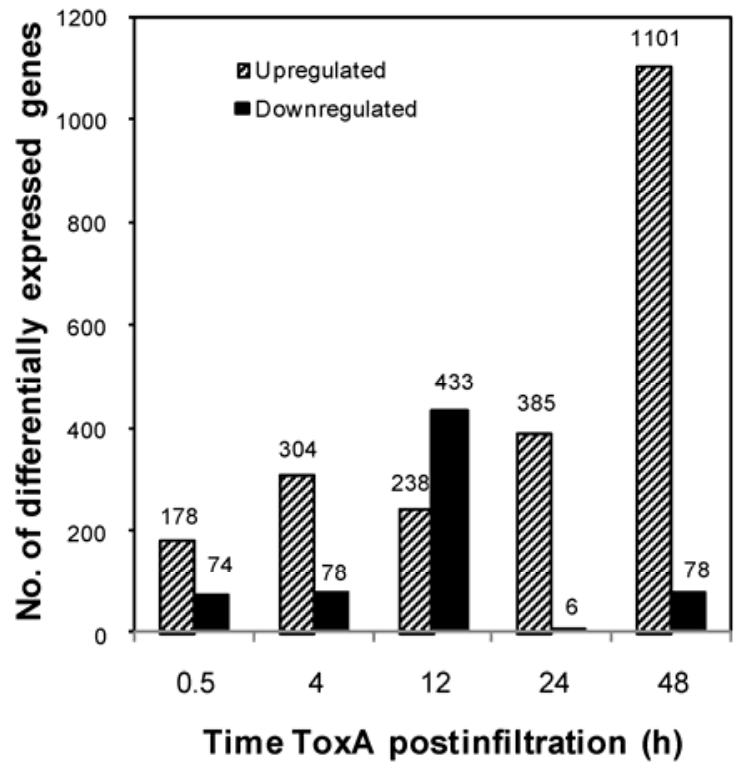

Fig. 2. Differential gene expression in the sensitive wheat cv. Kulm compared with the insensitive wheat cv. Nec103 after infiltration with ToxA (10 $\mu \mathrm{g} / \mathrm{ml}$ ) from Pyrenophora tritici-repentis. Total RNA was extracted from leaves at $0.5,4,12,24$, and $48 \mathrm{~h}$ postinfiltration and used for microarray analysis. Genes were considered differentially expressed if their fold change was $>2$ with $P \leq 0.05$. Cross-hatched bars represent the number of genes where transcription was significantly increased and solid bars indicate a decrease in RNA abundance. 
Induction of defense response and signal transduction genes during the compatible Tsn1-ToxA interaction.

A large number of genes modulated by ToxA were classified as defense related (Table 1). Approximately 154 upregulated and 36 downregulated genes are involved in defense at multiple timepoints after ToxA infiltration; these included genes encoding pathogenesis-related (PR) proteins, ROS-related enzymes (e.g., glutathione transferase, glutathione S-transferase, lipoxy-
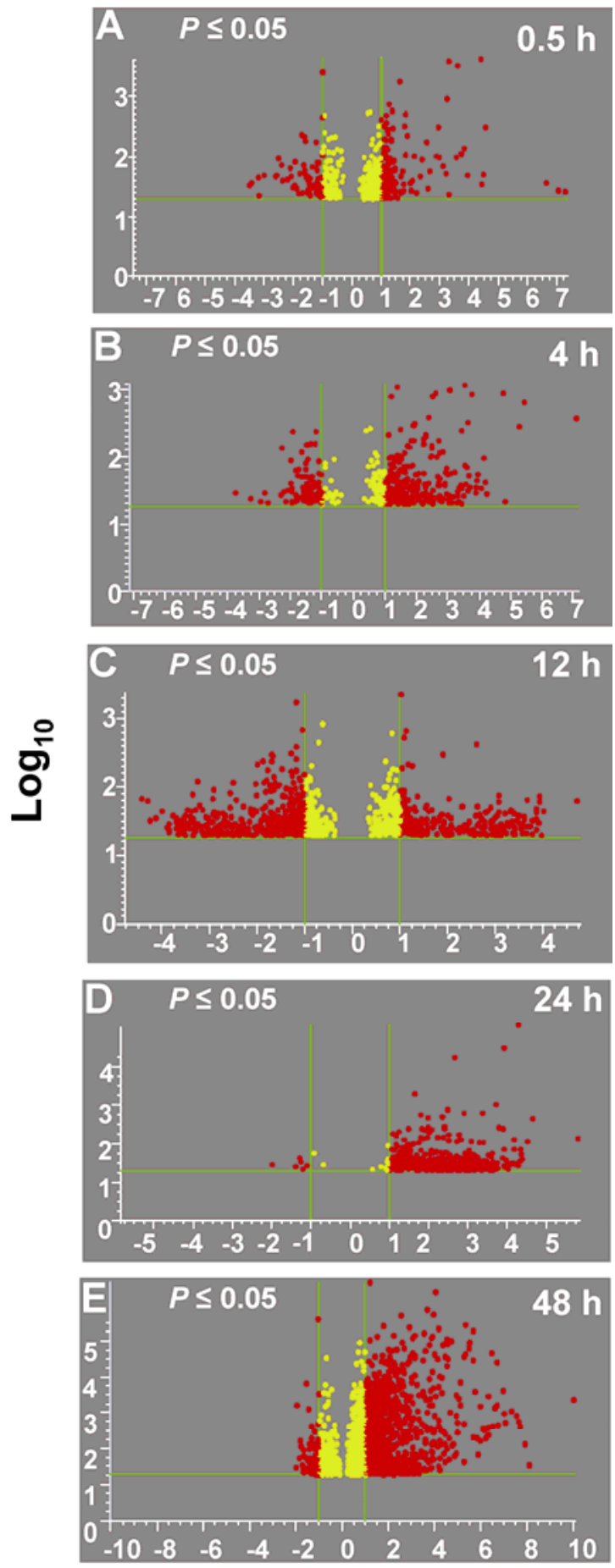

\section{$\log _{2}$ (fold change)}

Fig. 3. Cluster analysis showing differentially expressed genes in the toxinsensitive wheat cv. Kulm compared with the insensitive wheat cv. Nec103 at $0.5,4,12,24$, and $48 \mathrm{~h}$ after infiltration with ToxA $(10 \mu \mathrm{g} / \mathrm{ml})$ from Pyrenophora tritici-repentis. The discriminators $\log _{10}(P \leq 0.05)$ and $\log$ twofold change are indicated by horizontal and vertical green lines, respectively. genase, and peroxidase), cell-wall-modifying enzymes (chitinase and $\beta$-1,3-endoglucanase) (Table 1), and stress-related genes (germin-like protein, heat shock protein, osmotin, prolinerich protein, and thaumatin-like protein) (Supplementary Table S2). Interestingly, several genes involved in the phenylpropanoid pathway were induced, including chalcone synthase ( $\mathrm{CHS}$ ), lipoxygenase $(L O X)$, and phenylalanine ammonia lyase $(P A L)$. Genes repressed at early timepoints were amine oxidase (Ta.6420.2.S1_a_at), glutathione synthase (Ta.14856.1.S1_at), and peroxidases (Ta.27461.1.S1_a_at and Ta.12587.1.S1_at).

A significant number of genes encoding protein kinases (e.g., casein kinases, receptor-like protein kinases, and serine threonine kinases) and phosphatases also were induced at both early and late timepoints (Table 2). An ortholog (Ta.30053.1. $\mathrm{S} 1$ at) of Pto kinase was activated at $48 \mathrm{hpi}$, and genes encoding calcium-binding proteins and interactors (e.g., calmodulin and calmodulin-transporting ATPase) were upregulated at later timepoints. One of the signaling proteins, calmodulin (Ta.1018.2S1_×_at), was constitutively expressed in this study (Table 2). Several genes encoding proteins in the receptor kinase protein family were downregulated at early timepoints.

\section{Activation of genes related to metabolism, energy, transcription factors, and cellular transporters during the compatible Tsn1-ToxA interaction.}

Among genes related to energy and chloroplast biogenesis, 71 were upregulated and 26 were downregulated across all timepoints (Supplementary Table S3). Genes encoding chloroplast functions such as ribulosebisphosphate carboxylase (Ta.2752.1.S1_x_at) and mitochondrial precursors (e.g., Ta.7715.1.S1_at) were downregulated at 12 hpi. Among transcription factors, 24 upregulated and 5 downregulated genes were identified across all timepoints (Supplementary Table S4). The two major transcription factors identified in this study were Myb and zinc finger proteins. Seven ABC transporter genes were upregulated at the later stages of cell death (Supplementary Table S5).

\section{Expression of defense response and signaling genes using qPCR analysis.}

We used qPCR analysis to validate the expression of six genes associated with the plant defense response, including chitinase $(C H I), \beta$-1,3-glucanase $(P R-2)$, glutathione transferase $(G S T), P A L$, peroxidase $(P E R)$, and NADPH oxidase $(N A D)$. Three genes from established signal transduction pathways also were analyzed by qPCR, including calmodulin $(C a M)$, receptor-like kinase $(R L K)$, and serine threonine protein kinase $(P K)$. The expression of each gene was examined after the accumulation of mRNAs in a toxin-sensitive and a toxin-insensitive wheat cultivar at $0,4,8,12,14$, and $48 \mathrm{~h}$ after ToxA application. The relative fold changes in the wheat cultivars were compared with a mock inoculation $\left(\mathrm{H}_{2} \mathrm{O}\right)$ at each timepoint. Among the six genes from the defense response category, $\mathrm{CHI}$ displayed the highest induction in the ToxA-sensitive wheat cv. Kulm at 12 hpi (Fig. 5A). An increase in the expression of $P R$-2 was first observed at $8 \mathrm{hpi}$ (threefold) in Kulm but did not show maximal induction (sevenfold) until 48 hpi (Fig. 5B). Although there was a twofold induction of GST in Kulm at 4 hpi, induction was substantially higher (sevenfold) at 48 hpi (Fig. 5C). PAL was induced across all timepoints in cv. Kulm, with maximal expression at $48 \mathrm{hpi}$ (Fig. 5D). PAL also was induced (approximately fourfold) in the ToxA-insensitive Nec103 at 48 hpi (Fig. 5D). The PER gene was induced at 8 and 12 hpi (16-fold) in the ToxA-sensitive cv. Kulm; a slight induction of PER (two to threefold) also was observed at 24 hpi in Nec103 (Fig. 5E). Maximum induction (13-fold) of 
$N A D$ occurred in Kulm at 48 hpi (Fig. 5F), confirming that $N A D$ was expressed during the later stages of cell death.

The signaling gene $C a M$ was differentially induced in cv. Kulm at 4, 12, 24, and 48 hpi, with the highest induction (18fold) at 48 hpi (Fig. 5G). RLK was the most highly expressed gene in Kulm (50-fold increase at $48 \mathrm{hpi}$ ) and was not induced in the ToxA-insensitive Nec103 (Fig. 5H). The highest level of $P K$ induction was observed in the ToxA-sensitive Kulm at 48 hpi, with little to no induction in the ToxA-insensitive Nec103 (Fig. 5I). Overall, gene expression patterns determined by qPCR analysis were consistent and correlated with microarray analysis ( $r=0.914$, data not shown).

\section{Measurement of cell death using Evans blue.}

The survival of plant cells can be examined by staining tissue sections in a solution of Evans blue (Baker and Mock 1994). Viable cells exclude Evans blue at the plasma membrane and remain unstained, whereas dead cells are unable to exclude Evans blue and stain deep blue (Baker and Mock
1994). Previous investigations reported that a rapid loss of host cell membrane integrity occurs during cell death and can be monitored via electrolyte leakage assays (Meinhardt et al. 2002; Rasmussen et al. 2004). Thus, the relationship between cell death and dye uptake was monitored in the Tsn1-ToxA interaction using a spectrophotometer and by microscopic examination at early (12 hpi) and late (48 hpi) stages after ToxA infiltration. At 12 hpi, Evans blue uptake was higher in the ToxA-sensitive Kulm compared with the insensitive cv. Nec103 (Fig. 6A). Cell death measured by microscopy was higher in cv. Kulm compared with Nec103 (Fig. 6B). At 48 hpi, the estimated cell death by both methods (Evans blue uptake and microscopic evaluation) was more correlated in sensitive wheat than insensitive wheat and was significantly $(P \leq$ 0.01 ) different between two wheat cultivars (Fig. 6A and B).

\section{Detection of $\mathrm{H}_{2} \mathrm{O}_{2}$ using 3,-3'diaminobenzidine.}

Staining with $3,-3^{\prime}$ diaminobenzidine (DAB) is commonly used to detect $\mathrm{H}_{2} \mathrm{O}_{2}$ production during plant-pathogen interac-

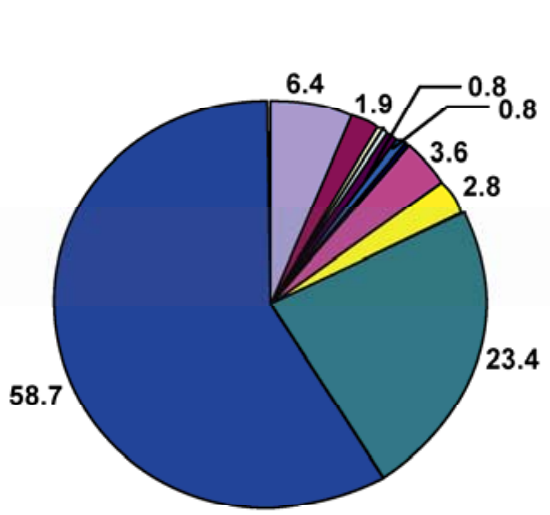

$0.5 \mathrm{~h}$

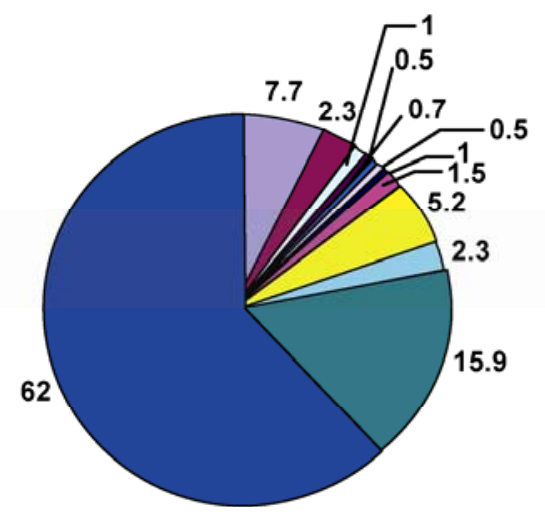

$4 \mathrm{~h}$

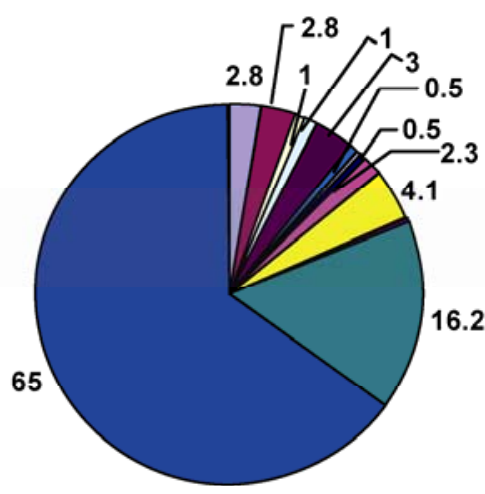

$12 \mathrm{~h}$

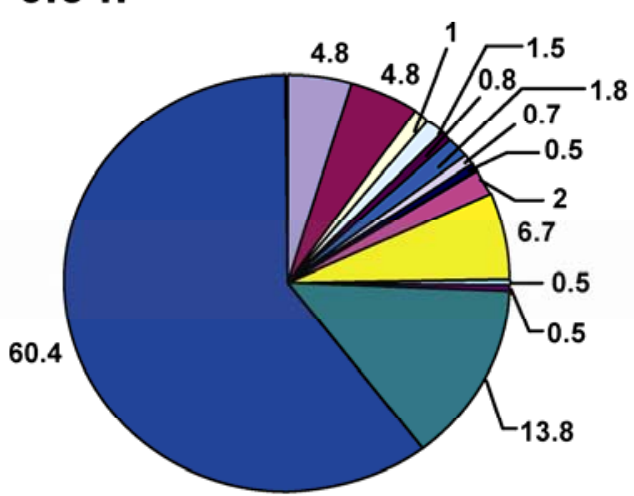

$24 \mathrm{~h}$
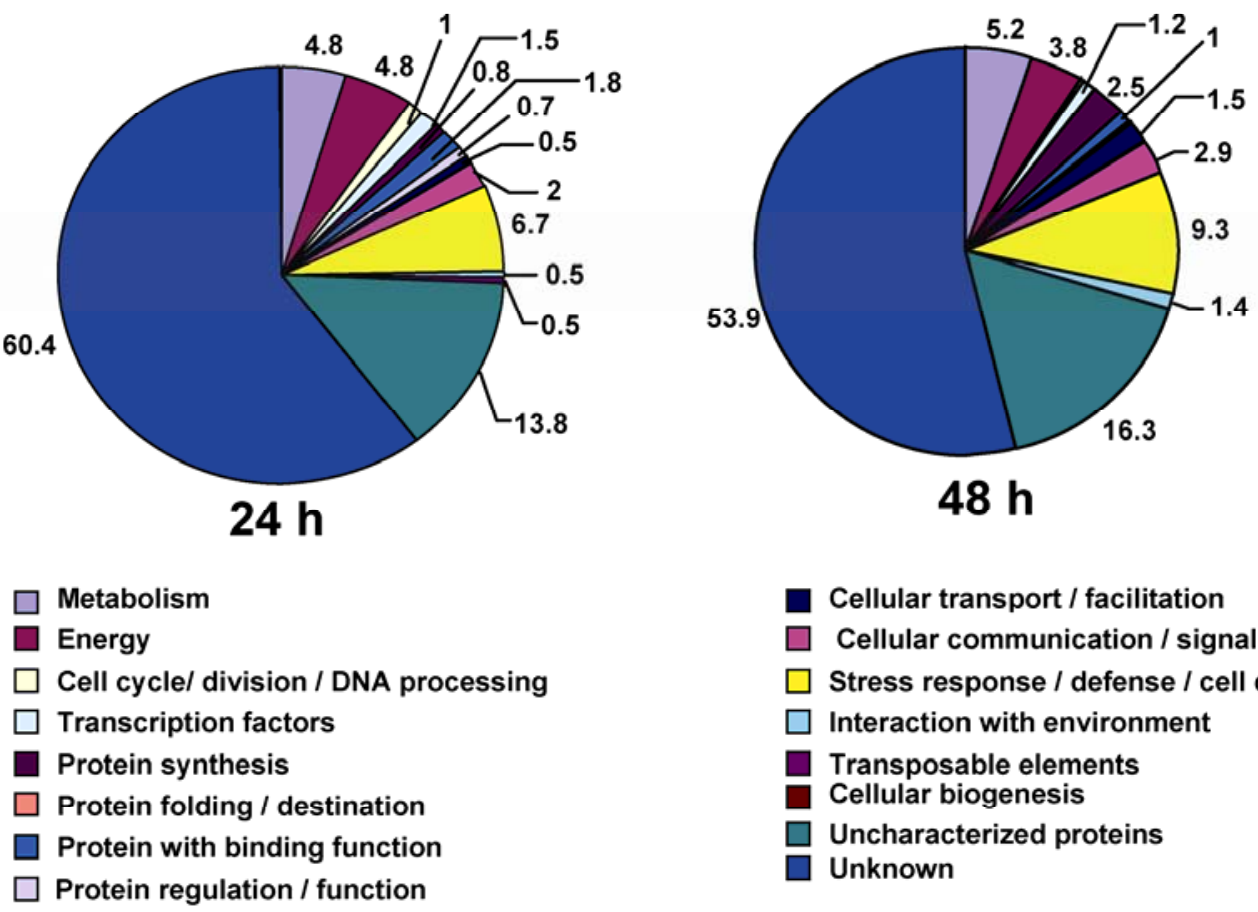

Cellular transport / facilitation

Cellular communication / signal transduction

Stress response / defense / cell death

$\square$ Interaction with environment

Transposable elements

- Cellular biogenesis

$\square$ Uncharacterized proteins

Unknown

Fig. 4. Pie charts showing classification of functional category genes that were differentially expressed at 0.5 , 4, 12, 24, and $48 \mathrm{~h}$ after infiltration of ToxA $(10 \mu \mathrm{g} / \mathrm{ml})$ from Pyrenophora tritici-repentis. Each gene was categorized to a functional class according to annotations assigned by MIPS (MIPS Arabidopsis thaliana Database) as described previously (Keon et al. 2007). Values represent the percentage of differentially expressed genes (fold-change values $>2.0$ ) after infiltration of the toxin-sensitive wheat cv. Kulm compared with the insensitive wheat line Nec103. Values <0.5\% in some functional categories are not shown. 
tions (Thordal-Christensen et al. 1997). Wheat segments infiltrated with water (control) or ToxA were collected from both sensitive and insensitive wheat cultivars at 4, 12, 24, and 48 hpi. $\mathrm{H}_{2} \mathrm{O}_{2}$ was not detected in leaf segments of Kulm or Nec103 when infiltrated with water (Fig. 7A through H). Similarly, no difference in $\mathrm{H}_{2} \mathrm{O}_{2}$ production in mesophyll cells was observed between sensitive and insensitive wheat cultivars at 4 hpi (Fig. 7I and M). DAB staining occurred in mesophyll cells undergoing ToxA-elicited cell death in the sensitive wheat cv. Kulm at 12 hpi (Fig. 7J). Extensive staining was detected at the stomatal aperture or near the periphery of guard cells in Kulm treated with ToxA (Fig. 7K), indicating the effect of DAB polymerization. ToxA-induced cell death became necrotic in Kulm, particularly at 48 hpi (Fig. 7L). In contrast, $\mathrm{H}_{2} \mathrm{O}_{2}$ was not detected in the ToxA-insensitive wheat cv. Nec103 (Fig. $7 \mathrm{M}$ through $\mathrm{P}$ ), which agrees with the absence of cell death. These results suggest a strong correlation between $\mathrm{H}_{2} \mathrm{O}_{2}$ production and the ability of ToxA to induce cell death in the ToxA-sensitive Kulm.

\section{DISCUSSION}

A combination of Affymetrix GeneChip Wheat Genome Array, qPCR assays, and histochemical methods was used to determine Tsn1-mediated host responses to ToxA. Aims of the present study were to determine what genes are induced in response to ToxA, and to compare ToxA-induced cell death in wheat to other plant-pathogen interactions. We show that the fungal virulence effector ToxA can induce cell death by altering host gene expression and cell physiology. Our data provide a conceptual framework for understanding the role of ToxA in modulating Tsn1-mediated defense and fungal pathogenesis. To our knowledge, induction of host cell death by ToxA follows mechanisms similar to $A v r-R$ gene model systems.

Many of the genes induced as a consequence of the Tsn1ToxA interaction allowed us to make comparisons with other compatible interactions (Restrepo et al. 2005; Thilmony et al. 2006). The numbers of differentially expressed genes were related to proteins and enzymes associated with defense, signal transduction, secondary metabolism, energy, transcription factors, and ATP-binding cassette (ABC) transporters. Our microarray analysis identified the expression patterns of several hundred genes in the Tsn1-ToxA interaction, and one of the challenges was how to utilize these large data sets. Thus, we chose two major functional gene categories that are modulated in the Tsn1-ToxA interaction (e.g., defense and signal transduction) (Tables 1 and 2).

In this study, Affymetrix GeneChip Wheat genome arrays identified numerous genes that were differentially expressed in the Tsn1-ToxA interaction, including genes encoding PR proteins associated with secondary metabolism and cell wall modifications (e.g., $P R-1, P R-2, P R-5$, and $P R 10$ ) and the phenylpropanoid pathway (e.g., $C H S, L O X$, and $P A L$ ). The expression patterns of selected genes were confirmed in an independent

Table 1. Differentially expressed representative genes involved in plant defense response revealed by microarray analysis of a toxin-sensitive wheat cultivar versus an insensitive wheat cultivar infiltrated with ToxA from Pyrenophora tritici-repentis

\begin{tabular}{|c|c|c|c|c|}
\hline Probe set $^{\mathrm{a}}$ & Putative function & Time (h) & Fold change $^{b}$ & $P$ value \\
\hline Ta.14946.1.S1_at & Basic chitinase & 48 & 4.1 & $1.64 \mathrm{E}-05$ \\
\hline Ta.26983.1.A1_at & Basic chitinase & 12 & 0.3 & 0.041 \\
\hline Ta.26983.1.A1_at & Basic chitinase & 48 & 3.2 & 0.001 \\
\hline \multirow[t]{2}{*}{ Ta.30501.1.S1_at } & Basic chitinase & 24 & 3.2 & 0.029 \\
\hline & & 48 & 5.5 & 0.001 \\
\hline \multirow[t]{2}{*}{ Ta.2784.1.A1_at } & Chitinase $1 / \mathrm{F}$ & 24 & 3 & 0.044 \\
\hline & & 48 & 4.7 & 0.009 \\
\hline \multirow[t]{2}{*}{ Ta.21342.1.S1_x_at } & Chitinase 3 & 24 & 13 & 0.010 \\
\hline & & 48 & 15 & $6.72 \mathrm{E}-05$ \\
\hline Ta.221.1.S1_at & Chitinase II precursor & 48 & 14.9 & $7.45 \mathrm{E}-06$ \\
\hline Ta.1830.2.S1_x_at & Glutathione $S$-transferase & 48 & 2.4 & 0.041 \\
\hline \multirow[t]{2}{*}{ Ta.3118.1.S1_at } & Glutathione $S$-transferase & 24 & 4.2 & 0.014 \\
\hline & & 48 & 2 & 0.001 \\
\hline Ta.25377.1.S1_at & Glutathione $S$-transferase & 48 & 4.9 & 0.001 \\
\hline Ta.3118.1.S1_at & Glutathione $S$-transferase & 24 & 4.2 & 0.014 \\
\hline Ta.25838.1.A 1 1_at & Glutathione $S$-transferase & 12 & 5.6 & 0.046 \\
\hline Ta.14856.1.S1_at & Glutathione synthase & 0.5 & 0.4 & 0.039 \\
\hline Ta.28354.1.S1_at & Glutathione transferase & 48 & 2 & 0.001 \\
\hline \multirow[t]{2}{*}{ Ta.3679.1.S1_x_at } & Glutathione transferase & 24 & 7 & 0.008 \\
\hline & & 48 & 4 & 0.006 \\
\hline \multirow[t]{2}{*}{ Ta.278.1.S1_at } & Pathogenesis-related protein 1 & 24 & 18.1 & 0.008 \\
\hline & & 48 & 50.1 & $5.01 \mathrm{E}-06$ \\
\hline \multirow[t]{2}{*}{ Ta.278.1.S1_x_at } & Pathogenesis-related protein 1 & 24 & 4 & 0.002 \\
\hline & & 48 & 45.2 & $1.01 \mathrm{E}-05$ \\
\hline Ta.8304.1.S1_a_at & Pathogenesis-related protein 1 & 24 & 10.9 & 0.010 \\
\hline Ta.30739.2.S1_at & Pathogenesis-related protein & 48 & 40 & $2.20 \mathrm{E}-05$ \\
\hline Ta.14010.3.S1_x_at & Peroxidase ATP19a & 4 & 5.1 & 0.041 \\
\hline \multirow[t]{2}{*}{ Ta.24015.1.A1_at } & Peroxidase ATP23a & 12 & 0.5 & 0.017 \\
\hline & & 48 & 3.7 & 0.015 \\
\hline Ta.12587.1.S1_at & Peroxidase ATP2a & 0.5 & 0.2 & 0.021 \\
\hline \multirow[t]{2}{*}{ Ta.21307.2.S1_x_at } & Peroxidase ATP4a & 4 & 4.8 & 0.035 \\
\hline & & 48 & 2.2 & 0.012 \\
\hline Ta.29496.1.S1_x_at & Peroxidase ATP4a & 48 & 5.2 & 0.001 \\
\hline Ta.30028.1.S1_x_at & Peroxidase ATP4a & 48 & 2.2 & 0.007 \\
\hline Ta.5235.1.S1_x_at & Peroxidase ATP4a & 48 & 7.7 & 0.005 \\
\hline \multirow[t]{2}{*}{ Ta.29603.1.A $\overline{1} \_$at } & Peroxidase $\mathrm{N}$ & 48 & 8.6 & 0.029 \\
\hline & & & & (continued on next page) \\
\hline
\end{tabular}

a Blank indicates that probe induced more than one time point.

${ }^{\mathrm{b}}$ Genes were considered to be differentially expressed if their fold change was $>2$ with $P \leq 0.05$. 
biological experiment by qPCR analysis and found to be highly correlated $(r=0.914)$ between microarray gene expression and qPCR gene expression. A previous study (Bolton et al. 2008) has also shown a high concordance between these two analyses. Consistent with our microarray analysis, most of these genes were induced as early as 4 hpi in sensitive wheat cv. Kulm infiltrated with ToxA. Local and systemic accumulation of PR proteins such as $P R-1, P R-2$, and $P R-5$ along with activation of the phenylpropanoid pathway have been implicated in plants exhibiting a hypersensitive response to fungal and bacterial pathogens (Balaji et al. 2008; Martin et al. 2003; Venisse et al. 2002). In addition, several comparative studies have shown marked differences in the temporal and spatial expression patterns of defense genes in compatible and incompatible plant-pathogen interactions (Joosten and de Wit 1989; Venisse et al. 2002). Genes encoding CHS, cinnamoyl-CoA reductases, $L O X, P A L$, and cytochrome $\mathrm{P} 450$ hydroxylases, which are involved in the phenylpropanoid pathway and electron transport, were induced in the $T s n 1-$ ToxA interaction in the present study (Fig. 8). These enzymes are important in the production of secondary metabolites that are necessary for lignin biosynthesis during cell wall thickening (Hahlbrock and Scheel 1989). In addition, defense-related secondary metabolites were previously shown to be generated from the hydroxylation of phenylalanine from cytochrome $\mathrm{P} 450$ hydroxylases (La Camera et al. 2004). In soybean, temporal changes in the expression of genes in the phenylpropanoid pathway were ob- served in both compatible and incompatible interactions (Zabala et al. 2006). In our study, numerous cytochrome $\mathrm{P} 450$ hydroxylases and $\mathrm{ABC}$ transporters were induced in the Tsn1-ToxA interaction. These results may indicate a role for these enzymes and transporters in producing defense-related secondary metabolites, and for transporting and utilizing these metabolites during the necrotrophic fungal lifestyle and pathogenesis.

Several lines of evidence suggest that ROS play important roles in the activation of plant defense via the reinforcement of cell walls (Bradley et al. 1992), the regulation of defense genes (Levine et al. 1994), and the production of toxic free radicals (Brisson et al. 1994). The production of ROS during plantpathogen interactions is one of the earliest cellular responses (Lamb and Dixon 1997). Potential enzyme sources for ROS include plasma membrane-located NADPH oxidase (Desikan et al. 2001), cell-wall-bound peroxidases, and amine oxidase (Desikan et al. 2001; Lamb and Dixon 1997). In this study, several anionic peroxidases, cationic peroxidases, and an NADPH oxidase were induced in the Tsn1-ToxA interaction. These membrane-bound enzymes may be major sources for ROS production, thus leading to cell death in ToxA-sensitive wheat. Several ROS-related enzymes, including germins, glutathione S-transferases, and a set of ROS marker genes (encoding heat shock protein, dirigent protein, HSP90-like protein, proline-rich protein, thaumatin-like protein, and osmotin), also were induced in sensitive wheat cultivars across all timepoints. Comparison of these results with previous findings (Dowd et

Table 1. (continued from preceding page)

\begin{tabular}{|c|c|c|c|c|}
\hline Probe set $^{\mathrm{a}}$ & Putative function & Time (h) & Fold change $^{b}$ & $P$ value \\
\hline Ta.20985.1.A1_at & Peroxidase & 12 & 9.1 & 0.038 \\
\hline Ta.12472.1.S1_x_at & Peroxidase & 4 & 2.2 & 0.046 \\
\hline Ta.13307.3.S1_at & Peroxidase & 48 & 2.7 & 0.013 \\
\hline Ta.18560.1.S1_s_at & Peroxidase & 48 & 3.5 & 0.006 \\
\hline Ta.21505.1.S1_at & Peroxidase & 48 & 2.2 & 0.005 \\
\hline \multirow[t]{2}{*}{ Ta.22564.1.S1_at } & Peroxidase & 24 & 5.3 & 0.016 \\
\hline & & 48 & 15.8 & 0.003 \\
\hline Ta.22564.2.S1_a_at & Peroxidase & 48 & 197.3 & 0.018 \\
\hline Ta.22564.2.S1_x_at & Peroxidase & 48 & 81.4 & 0.003 \\
\hline Ta.22593.1.A1_at & Peroxidase & 48 & 2.5 & 0.002 \\
\hline \multirow[t]{2}{*}{ Ta.22593.2.S1_X_at } & Peroxidase & 4 & 4.6 & 0.050 \\
\hline & & 48 & 2.6 & 0.013 \\
\hline Ta.24710.1.S1_at & Peroxidase & 48 & 8.3 & 0.009 \\
\hline Ta.26230.1.S1_at & Peroxidase & 48 & 2.7 & 0.001 \\
\hline Ta.26230.1.S1_x_at & Peroxidase & 48 & 5.5 & 0.002 \\
\hline Ta.26230.2.S1_at & Peroxidase & 48 & 15.8 & 0.007 \\
\hline Ta.27461.1.S1_a_at & Peroxidase & 0.5 & 0.4 & 0.032 \\
\hline Ta.5406.1.S1_at & Peroxidase & 12 & 0.5 & 0.024 \\
\hline Ta.7816.1.A1_at & Peroxidase & 12 & 0.18 & 0.032 \\
\hline \multirow[t]{2}{*}{ Ta.82.1.S1_at } & Peroxidase & 24 & 4.2 & 0.039 \\
\hline & & 48 & 11.2 & 0.001 \\
\hline Ta.962.1.A1_at & Peroxidase & 48 & 3.3 & 0.003 \\
\hline Ta.28182.1.A1_x_at & Phenylalanine ammonia lyase & 48 & 3.2 & 0.012 \\
\hline Ta.7022.1.S1_at & Phenylalanine ammonia lyase & 48 & 3.1 & 0.007 \\
\hline Ta.7022.1.S1_s_at & Phenylalanine ammonia lyase & 48 & 3.3 & 0.005 \\
\hline Ta.7022.1.S1_x_at & Phenylalanine ammonia lyase & 48 & 3.1 & 0.005 \\
\hline Ta.7022.2.S1_at & Phenylalanine ammonia lyase & 48 & 2.7 & 0.046 \\
\hline Ta.7022.2.S1_x_at & Phenylalanine ammonia lyase & 48 & 2.3 & 0.048 \\
\hline \multirow[t]{2}{*}{ Ta.9220.1.S1_a_at } & Phenylalanine ammonia lyase & 24 & 3.7 & 0.026 \\
\hline & & 48 & 7.9 & 0.001 \\
\hline Ta.21208.1.S1_at & Putative superoxide generating NADPH oxidase & 4 & 4.2 & 0.041 \\
\hline Ta.21028.3.S1_at & Putative superoxide-generating NADPH oxidase & 0.5 & 2.3 & 0.003 \\
\hline Ta.10.1.S1_a_at & $\beta-1,3 ; 1,4$-glucanase & 4 & 5.7 & 0.032 \\
\hline Ta.10.1.S1_x_at & $\beta-1,3 ; 1,4$-glucanase & 4 & 6.7 & 0.021 \\
\hline \multirow[t]{2}{*}{ Ta.8584.1.S1_at } & $\beta-1,3$-glucanase class I precursor & 24 & 7 & 0.030 \\
\hline & & 48 & 19.6 & 0.001 \\
\hline \multirow[t]{2}{*}{ Ta.223.1.S1_at } & $\beta$-1,3-glucanase precursor & 12 & 0.3 & 0.011 \\
\hline & & 48 & 7.3 & 0.001 \\
\hline Ta.225.1.S1_at & $\beta$-1,3-glucanase precursor & 48 & 32.6 & 0.001 \\
\hline Ta.22562.1.S1_at & $\beta$-1,3-glucanase & 48 & 2.3 & 0.006 \\
\hline Ta.21354.1.A1_at & $\beta$-1,3-glucanase-like protein & 48 & 14.2 & 0.001 \\
\hline
\end{tabular}


al. 2004; Moy et al. 2004; Shimizu et al. 2007) suggests commonalities with respect to elevated expression of host defense response genes during compatible interactions. Our results indicate that the cell death associated with ROS in the presence of ToxA plays an important role in developing necrotic symptoms in sensitive wheat. Furthermore, a common mechanism is likely to exist for $T s n 1$-mediated susceptibility and $R$ gene-mediated plant immunity in response to plant pathogens (Hammond-Kosack and Jones 1996; Martin et al. 2003).

The most striking evidence for the involvement of ROS in cell death in the present study was based on the quantitative measurement of dye uptake (estimated by a spectrophotometer) and $\mathrm{H}_{2} \mathrm{O}_{2}$ production detected by DAB staining. Darkbrown regions were visible after DAB staining in ToxA-treated sensitive wheat between 12 and 48 hpi (Fig. 7J, K, and L). However, $\mathrm{H}_{2} \mathrm{O}_{2}$ did not accumulate in the ToxA-insensitive wheat Nec103 even at 48 hpi (Fig. 7P). Our histochemical analyses show that ROS is a major signal leading to the development of cell death in ToxA-sensitive wheat, and may be a pivotal step in the development of necrosis in wheat infected by Pyrenophora tritici-repentis. Photosystem II is regarded as a major source of the large, secondary oxidative burst in hypersensitive response-associated resistance (Lamb and Dixon 1997). As reported previously, ToxA acts on the chloroplasts of sensitive wheat (Manning and Ciuffetti 2007). A notable change that we observed in the present study was the downregulation of several chloroplast-related genes such as chloroplast ribulosebisphosphate carboxylase and ribosomal proteins, and

Table 2. Differentially expressed representative genes involved in signal transduction revealed by microarray analysis of a toxin-sensitive wheat cultivar versus an insensitive wheat cultivar infiltrated with ToxA from Pyrenophora tritici-repentis

\begin{tabular}{|c|c|c|c|c|}
\hline Probe set $^{\mathrm{a}}$ & Putative function & Time (h) & Fold change $^{b}$ & $P$ value \\
\hline Ta.1018.1.S1_x_at & Calmodulin & 48 & 2.9 & 0.001 \\
\hline \multirow[t]{5}{*}{ Ta.1018.2.S1_x_at } & Calmodulin 7 & 0.5 & 9.5 & 0.001 \\
\hline & & 4 & 8.3 & 0.001 \\
\hline & & 12 & 3.8 & 0.031 \\
\hline & & 24 & 4.5 & 0.016 \\
\hline & & 48 & 8.3 & $2.16 \mathrm{E}-05$ \\
\hline Ta.7730.2.S1_a_at & Calmodulin-binding protein homolog & 48 & 2.3 & 2.35E-07 \\
\hline Ta.7730.1.A1_at & Calmodulin-binding protein homolog & 48 & 2.7 & 0.093 \\
\hline Ta.23713.1.A1__at & Protein kinase & 48 & 8.2 & 0.043 \\
\hline Ta.15958.1.3.S1_at & Protein kinase & 48 & 2.3 & 0.008 \\
\hline Ta.1674.1.S1_x_at & Protein kinase & 48 & 7.2 & 0.001 \\
\hline Ta.1674.2.S1_s_at & Protein kinase & 48 & 6 & 0.001 \\
\hline Ta.13013.2.S1_x_x_at & Protein kinase & 48 & 3.6 & 0.001 \\
\hline Ta.17696.1.A1_at & Protein kinase & 24 & 4.2 & 0.039 \\
\hline Ta.7752.1.S1_x_at & Protein kinase & 24 & 2.2 & 0.006 \\
\hline Ta.8400.2.S1_at & Protein kinase & 12 & 8 & 0.432 \\
\hline Ta.23679.1.S1__at & Protein phosphatase $2 \mathrm{C}$-like protein & 48 & 3.5 & $9.70 \mathrm{E}-05$ \\
\hline Ta.27767.1.S1_at & Protein phosphatase $2 \mathrm{C}$ & 48 & 7.2 & 0.041 \\
\hline Ta.23713.1.A1_x_at & Putative protein kinase & 24 & 9.2 & 0.043 \\
\hline Ta.10207.1.S1_at & Putative protein phosphatase $2 \mathrm{C}$ & 48 & 2 & 0.015 \\
\hline \multirow{2}{*}{ Ta.6517.1.S1_x_at } & Protein phosphatase $2 \mathrm{C}$ & 4 & 2.2 & 0.039 \\
\hline & & 24 & 4.2 & 0.03 \\
\hline Ta.30053.1.S1_at & Pto kinase interactor & 48 & 2.4 & 0.032 \\
\hline Ta.22697.2.A1_at & Putative casein kinase II & 12 & 0.4 & 0.429 \\
\hline \multirow[t]{2}{*}{ Ta.22269.1.A1_a_at } & Putative casein kinase & 0.5 & 6.1 & 0.018 \\
\hline & & 24 & 5.1 & 0.002 \\
\hline \multirow[t]{3}{*}{ Ta.22269.1.A1_at } & Putative casein kinase & 0.5 & 97.5 & 0.027 \\
\hline & & 4 & 38.5 & 0.004 \\
\hline & & 48 & 90 & 0.002 \\
\hline Ta.12127.1.A1_at & Receptor-like protein kinase & 48 & 3.6 & 0.017 \\
\hline Ta.29629.1.S1_s_at & Putative receptor-like protein kinase & 12 & 0.5 & 0.030 \\
\hline Ta.29629.2.S1_a_at & Putative receptor-like protein kinase & 0.5 & 0.4 & 0.031 \\
\hline Ta.5331.1.A1_x_at & Receptor protein kinase-like protein & 48 & 2.1 & 0.001 \\
\hline \multirow[t]{3}{*}{ Ta.24562.1.A1_at } & Receptor-like protein kinase & 0.5 & 5.2 & 0.011 \\
\hline & & 24 & 4.8 & 0.041 \\
\hline & & 48 & 9 & 0.027 \\
\hline Ta.5331.1.A1_a_at & Receptor protein kinase-like protein & 48 & 2.4 & 0.001 \\
\hline Ta.8590.1.S1_s_at & Receptor protein kinase-like protein & 48 & 2.1 & 0.002 \\
\hline Ta.8590.2.S1_a_at & Receptor protein kinase-like protein & 48 & 2.4 & 0.002 \\
\hline Ta.8590.2.S1_at & Receptor protein kinase-like protein & 48 & 2.3 & 0.045 \\
\hline Ta.12007.2.S1__at & Receptor serine threonine protein kinase & 48 & 2.3 & 0.002 \\
\hline Ta.25397.1.S1_at & Receptor-like kinase & 48 & 3.7 & 0.002 \\
\hline Ta.941.1.A1_at & Receptor-like protein kinase - like protein & 4 & 136.6 & 0.026 \\
\hline Ta.3929.2.A $\overline{1} \_a \_a t$ & Receptor-like protein kinase & 48 & 3.8 & 0.046 \\
\hline Ta.18480.2.S1_at & Receptor-like protein kinase & 12 & 0.1 & 0.002 \\
\hline \multirow[t]{2}{*}{ Ta.22666.1.S1_at } & Receptor-like protein kinase & 12 & 0.2 & 0.482 \\
\hline & & 48 & 3.3 & 0.001 \\
\hline Ta.5161.2.S1_x_at & Receptor-like protein kinase & 0.5 & 0.5 & 0.012 \\
\hline Ta.14561.3.S1_at & Receptor-protein kinase-like protein & 24 & 11.9 & 0.045 \\
\hline Ta.28502.2.S1_at & Serine threonine kinase & 12 & 13.3 & 0.037 \\
\hline Ta.5041.2.S1_a_at & Serine threonine kinase & 0.5 & 0.5 & 0.044 \\
\hline Ta.12156.1.A1_at & Serine threonine protein kinase & 0.5 & 3.4 & 0.029 \\
\hline Ta.4106.1.A1_at & Serine threonine-specific protein kinase & 48 & 2.6 & 0.001 \\
\hline
\end{tabular}

a Blank indicates that probe induced more than one time point.

${ }^{\mathrm{b}}$ Genes were considered as differentially expressed if their fold change was $>2$ with $P \leq 0.05$. 
transcription factor genes (e.g., translation elongation factors), in response to ToxA. Thus, it is possible that the inhibition of photosystem activity in the chloroplast due to ToxA may lead to high levels of ROS that can impact cellular homoeostasis (Lamb and Dixon 1997; Manning et al. 2009) We hypothesize that the photosystem of toxin-sensitive chloroplasts could be the origin of ROS in the Tsn1-ToxA interaction.

Evidence exists that the calcium signaling and protein phosphorylation cascades may be necessary for ToxA-induced cell death (Rasmussen et al. 2004). The majority of signaling transcripts accumulated during cell death in the present study were attributed to protein kinases (e.g., casein kinases, protein kinases, receptor-like kinases, and serine threonine kinases) and phosphatases. The products of these genes could play an important role in signal transduction after ToxA is perceived by the host receptor. Similarly, two MAPK (TaMPK3 and TaMPK6) were induced differentially during compatible interactions between wheat and Mycosphaerella graminicola (Rudd et al. 2008). Interestingly, the calmodulin gene (Ta.1018.2.S1_×_at) was expressed constitutively in response to ToxA. The expression of genes involved in calmodulin and
NADPH oxidase suggests a possible role in cross talk between calcium and ROS signaling in ToxA-mediated cell death.

In the current study, we assumed that the ToxA-insensitive wheat cv. Nec103 lacks a receptor for ToxA; consequently, ToxA would not be recognized in the insensitive cultivar. In support of this hypothesis, $\mathrm{H}_{2} \mathrm{O}_{2}$ production and cell death were absent in ToxA-treated Nec103. Although most of the defense-related genes monitored by qPCR (Fig. 5A through F) were downregulated in insensitive Nec103, a few genes (e.g., $P A L$ and $P E R$ ) showed some induction in this cultivar. It has been shown that defense response genes are closely associated with quantitative trait loci or $R$ genes in several cereal diseases (Faris et al. 1999, Liu et al. 2004). Future studies designed to investigate gene expression in incompatible Nec103-ToxA interaction are warranted.

\section{Conclusion.}

To gain insight into the molecular processes in the Tsn1ToxA interaction, we used microarray analysis to identify differentially expressed genes in ToxA-sensitive and -insensitive wheat cultivars. Host gene expression remained relatively low
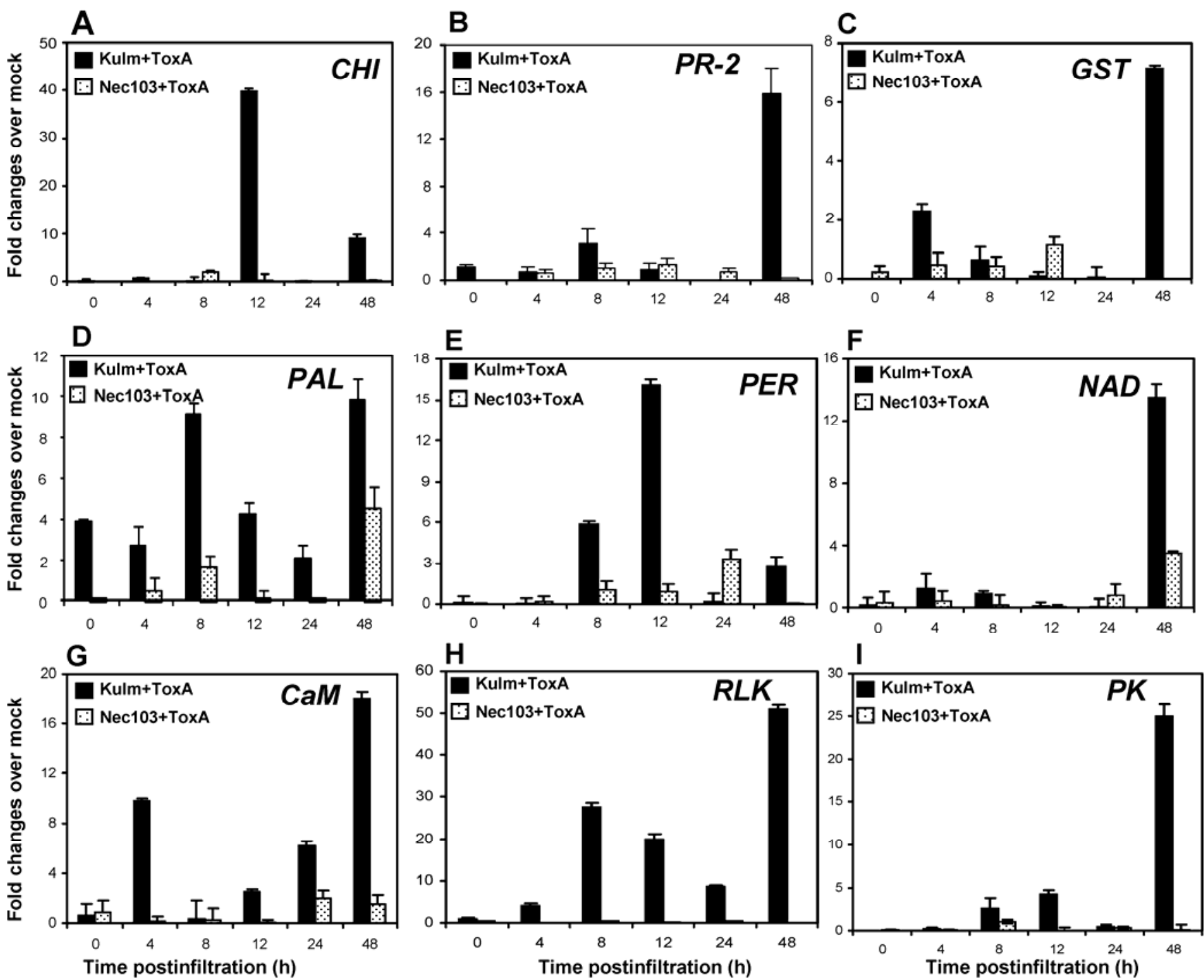

Fig. 5. Validation of differentially expressed representative genes using real-time polymerase chain reaction (qPCR) assays. The expression of nine genes was investigated in the ToxA-sensitive wheat cv. Kulm and compared with insensitive mutant wheat line Nec103 after infiltration with ToxA (10 $\mu$ g/ml) from Pyrenophora tritici-repentis. The relative expression of each gene was calculated relative to the $\mathrm{H}_{2} \mathrm{O}$-infiltrated control from 0 to 48 hostinfiltration. Genes analyzed by qPCR assays include $\mathbf{A}$, chitinase $(C H I) ; \mathbf{B}, \beta-1$-3-glucanase $(P R-2)$; $\mathbf{C}$, glutathione transferase $(G S T)$; D, phenylalanine ammonia lyase $(P A L)$; $\mathbf{E}$, peroxidase $(P E R) ; \mathbf{F}$, NADPH oxidase $(N A D) ; \mathbf{G}$, calmodulin $(C a M) ; \mathbf{H}$, receptor kinase $(R L K)$, and $\mathbf{I}$, serine threonine protein kinase $(P K)$. Error bars represent standard deviations of the measurements for three replications at each timepoint. 
during the early timepoints prior to cell death, with a substantial increase in gene induction at 24 and 48 hpi when ToxA triggered extensive cell death. Our study supports the hypothesis that chloroplasts may be the origin of ROS production in the Tsn1-ToxA interaction. We propose that recognition of ToxA by its cognate host receptor occurs in ToxA-sensitive wheat but not in insensitive wheat. Specific signaling pathways appear to be activated due to up- and downregulation of transcription factors such as the Myb and zinc finger proteins (Fig. 8), suggesting complex positive and negative modulation of Tsn1-mediated metabolic pathways. These pathways activate protein phosphorylation, alter $\mathrm{Ca}^{2+}$ levels, and modulate enzymes involved in the production of ROS and phenylpropanoid biosynthesis (Fig. 8). This transcriptional reprogramming results in the induction and repression of genes involved in the plant defense response, cell wall modification, photosynthesis, and chloroplast biogenesis. We conclude that similar host responses are activated during the recognition of avirulence gene products (effectors) and elicitor-like proteins (ToxA) during the $R$-gene-mediated resistance to biotrophic fungi and susceptibility to necrotrophic fungi, respectively. This study generated an extensive list of potential candidate
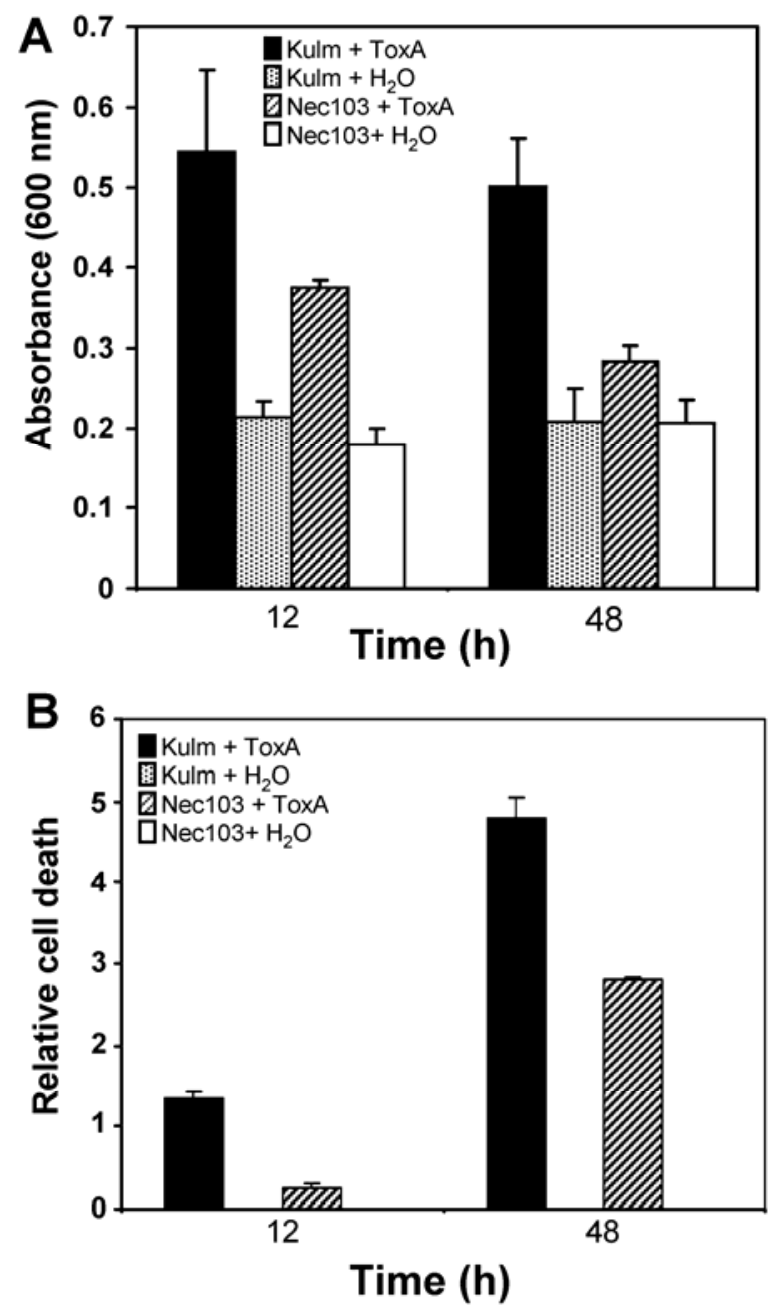

Fig. 6. Detection of Evans blue uptake in sensitive wheat cv. Kulm and insensitive mutant wheat line Nec103 after infiltration with ToxA $(10 \mu \mathrm{g} / \mathrm{ml})$ from Pyrenophora tritici-repentis at 12 and $48 \mathrm{~h}$ postinfiltration. For both experiments, leaf segments $(5 \mathrm{~cm}$ long) were collected from the two wheat cultivars (a total of 10 from two biological replicates). Cell death values were obtained by monitoring the retention of Evans blue by $\mathbf{A}$, spectrophotometry or $\mathbf{B}$, microscopic examination. Error bars represent standard deviations of the measurements for three replications at each timepoint. genes that can regulate the successful establishment of infection in sensitive wheat plants. Functional analysis of candidate genes will advance our understanding of the molecular processes of plant susceptibility to $P$. tritici-repentis.

\section{MATERIALS AND METHODS}

\section{Selection of wheat cultivars.}

The hard red spring wheat cv. Kulm, sensitive to ToxA and susceptible to $P$. tritici-repentis (Friesen et al. 2003), was selected as the toxin-sensitive cultivar. The wheat line Nec103, which was previously developed by mutagenesis (Friesen et al. 2002), was used as a toxin-insensitive cultivar. To identify genes in the $T s n 1-$ ToxA interaction and validate gene expression patterns, several precautions were adopted to reduce biological variation. First, all experiments were conducted in an environmental growth chamber to provide controlled conditions for all timepoints. Next, fully expanded secondary leaves of 2-week-old wheat seedlings were infiltrated with ToxA, which was purified from $P$. tritici-repentis as described below. Unless otherwise stated, two independent experiments were conducted on different days to represent two biological replicates. Each experiment was carried out three times to represent three technical replicates. Infiltration with sterile distilled $\mathrm{H}_{2} \mathrm{O}$ was included in each experiment to represent a mock-inoculated control.

\section{RNA isolation and experimental design.}

$P$. tritici-repentis number $86-124$, an isolate of race 2, produces Ptr ToxA (Strelkov and Lamari 2003) and was obtained from Dr. L. Lamari, University of Manitoba, Canada, and maintained at the Department of Plant Pathology, North Dakota State University. ToxA was purified and characterized from $P$. tritici-repentis isolate number 86-124 as described previously (Zhang et al. 1997). To identify host genes triggered by ToxA, seedling bioassays were performed, and a $10-\mu \mathrm{l}$ aliquot of purified ToxA $(10 \mu \mathrm{g} / \mathrm{ml})$ was infiltrated into the second leaf of each seedling using a 1-ml needleless syringe (Kwon et al. 1998). The infiltrated area was marked with a nontoxic permanent marker. Immediately after toxin infiltration, plants were maintained in growth chambers at a temperature regime of 21 and $18^{\circ} \mathrm{C}$ (light and darkness, respectively) and a 16-h photoperiod. To compare visual reactions, wheat cvs. Glenlea (sensitive to ToxA) and Salamouni (insensitive to ToxA) were included as controls. The entire experiment was conducted using a factorial split-plot design with three replications, where wheat cultivars and timepoints were represented as the main plot and subplot, respectively (Gomez and Gomez 1984). Each plastic cone was $3.8 \mathrm{~cm}$ in diameter and $20 \mathrm{~cm}$ long (Stuewe and Sons, Inc. Tangent, OR, U.S.A.), contained three seedlings per cone, and was regarded as a sampling unit, and two independent experiments were conducted.

After ToxA infiltration, total RNA was purified from the ToxA-sensitive wheat cv. Kulm and the insensitive wheat cv. Nec103 using TRIzol reagent (Invitrogen Life Technologies, Carlsbad, CA, U.S.A.). Total RNA was extracted from three seedlings per treatment and, following extraction, total RNAs were pooled to represent one biological replicate. For microarray analyses, leaf samples from both ToxA-sensitive and ToxA-insensitive wheat cultivars were collected at $0.5,4,12$, 24, and $48 \mathrm{hpi}$. Prior to microarray analysis, RNA integrity was evaluated using an Agilent 2100 bioanalyzer (Agilent Technologies, Palo Alto, CA, U.S.A.). RNA preparation, purification, and labeling were performed as described previously (Hulbert et al. 2007). Approximately $5 \mu \mathrm{g}$ of total RNA was used for first-strand cDNA and second-strand cDNA synthesis; cRNA synthesis and cRNA labeling were conducted as recom- 
mended by the manufacturer (Affymetrix, Inc., Santa Clara, CA, U.S.A.). cDNA $(15 \mu \mathrm{g})$ was used for hybridization.

\section{Gene expression profiling}

during the Tsn1-ToxA interaction.

The Affymetrix GeneChip Wheat Genome Arrays contain 61,127 probe sets representing 55,052 transcripts, which cover all 21 wheat chromosomes (Affymetrix). Each probe set contained 11 matched and 11 mismatched 25-mer oligonucleotides and was regarded as a transcript (Hulbert et al. 2007). The standard protocol used for microarray analysis was developed by Affymetrix and optimized by the Kansas State University Integrated Genomics Facility, Manhattan. Data analysis was performed using Genespring software (Agilent Technologies) as described previously (Hulbert et al. 2007). Analysis of variance was performed with three biological replicates to determine the effect of ToxA in a sensitive wheat cultivar versus an insensitive wheat cultivar. Differential gene expression in response to ToxA was classified as either qualitative or quantitative, depending on transcript detection patterns (present or absent) or transcript abundance differences, respectively. Fold changes were calculated as sensitive wheat cultivar values divided by insensitive wheat cultivar values. A gene was re- garded as differentially expressed if the fold change was $>2.0$ and $P$ was $\leq 0.05$. Differentially expressed genes (up- and downregulated) were classified according to functional categories using the MIPS Arabidopsis thaliana Database as described previously (Keon et al. 2007).

\section{qPCR analysis.}

Planting of wheat seed was performed as described above. Leaf tissues of both sensitive and insensitive wheat cultivars were infiltrated with ToxA as described previously (Kwon et al. 1998). Two-week-old seedlings were spray inoculated and transferred to a mist chamber ( $100 \%$ relative humidity) to provide continuous leaf wetness for $24 \mathrm{~h}$. Next, the plants were transferred into a growth chamber and maintained at 21 and $18^{\circ} \mathrm{C}$ (light and darkness, respectively) with a 16-h photoperiod. Leaf tissues from both wheat cultivars were collected at $0,4,8,12,24$, and 48 hpi. A mock inoculation consisting of infiltrated water was used as a control. The entire experiment was conducted using a factorial split-split-plot design with three replications, where wheat cultivars, ToxA infiltration or pathogen inoculation, and timepoints were represented as main plot, subplot, and sub-subplot, respectively (Gomez and Gomez 1984).

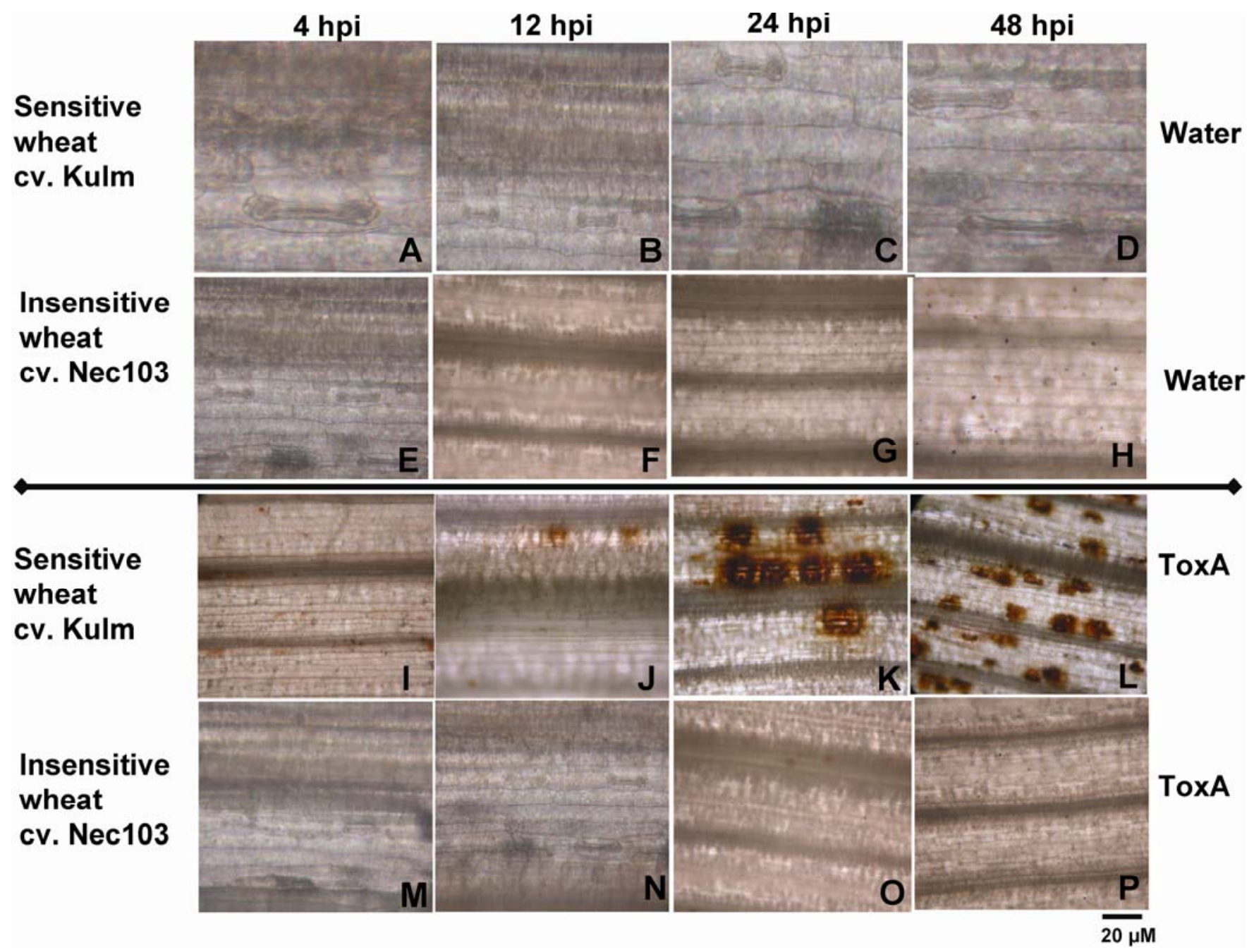

Fig. 7. Detection of $\mathrm{H}_{2} \mathrm{O}_{2}$ production and cell death in the ToxA-sensitive wheat cv. Kulm and the insensitive wheat line Nec103 infiltrated with $\mathrm{H}_{2} \mathrm{O}$ and ToxA $(10 \mu \mathrm{g} / \mathrm{ml})$ from Pyrenophora tritici-repentis. For each experiment, leaf segments (5 cm long) were collected from the two wheat cultivars (a total of 10 segments from two biological replicates). Leaf tissues were stained with $3,-3$ 'diaminobenzidine (DAB), and $\mathrm{H}_{2} \mathrm{O}_{2}$ was assessed using a digital stereomicroscope. A through $\mathbf{H}$, Upper panels show leaves infiltrated with $\mathrm{H}_{2} \mathrm{O}$ and $\mathbf{I}$ through $\mathbf{P}$, lower panels show leaves infiltrated with ToxA. Kulm infiltrated with water at A, 4 h postinfiltration (hpi); B, 12 hpi; C, 24 hpi; and D, 48 hpi. Nec103 infiltrated with water at E, 4 hpi; F, 12 hpi; G, 24 hpi; and H, 48 hpi. Kulm infiltrated with ToxA at I, 4 hpi; J, 12 hpi; K, 24 hpi; and L, 48 dpi. Nec103 infiltrated with ToxA at M, 4 dpi; N, 12 h; O, 24 dpi; and P, 48 dpi. 
For qPCR analysis, total RNA and cDNA were prepared as described previously (Adhikari et al. 2007). Briefly, $100 \mathrm{mg}$ of ground leaf powder was transferred into sterile $1.5-\mathrm{ml}$ centrifuge tubes, and total RNA was extracted using TRIzol reagent (Invitrogen Life Technologies). Random hexamers were used as the first-strand cDNA primer (Promega Corporation, Madison, WI, U.S.A.). The cDNA concentration of each sample was quantified using a NanoDrop spectrophotometer (Model ND1000; Thermo Scientific Inc., Waltham, MA, U.S.A.). Six genes involved in either the plant defense response or ROS production were analyzed for expression and included $\mathrm{CHI}$ (Ta.21342.1.S1_×_at), PR-2 (Ta10.1.S1_a_at), GST (Ta.3679. 1.S1_×_at), $P E R$ Ta.82.1.S1_at), $P A L$ (Ta.9220.1.S1_a_at), and NAD (Ta.21208.1.S1_at). Three genes involved in signal transduction were also monitored and included CaM (Ta.1018. 2.S1_×_at), $R L K$ (Ta.24562.1.A1_at), and $P K$ (Ta.28502.2. S1_at). Analysis of these genes was confirmed by qPCR at 0 , $4,8,12,24$, and 48 hpi with ToxA. The $18 \mathrm{~S}$ ribosomal RNA gene from wheat was used as an internal control (Adhikari et al. 2007). cDNA was prepared from the ToxA-sensitive Kulm infiltrated with ToxA at $48 \mathrm{hpi}$; this cDNA preparation was serially diluted and 10 -fold dilutions (100 to $0.01 \mathrm{ng} / \mu \mathrm{l}$ ) were used to generate a standard curve for each gene. Primer pairs for qPCR analyses (Supplementary Table S1) were selected using the same criteria as described previously (Adhikari et al. 2007). Each qPCR reaction $(10 \mu \mathrm{l})$ contained $1 \times$ SYBR Green PCR Master Mix (Applied Biosystems, Inc., Foster City, CA, U.S.A.), $10 \mathrm{ng}$ of cDNA template per reaction, and 4 to $7 \mu \mathrm{M}$ each forward and reverse gene-specific primer. All qPCR were performed using the Stratagene Mx3005P System (Agilent Technologies). The protocol used for PCR reactions was as follows: preincubation at $25^{\circ} \mathrm{C}$ for $2 \mathrm{~min}$; denaturation at $95^{\circ} \mathrm{C}$ for $10 \mathrm{~min}$; and 45 cycles at $95^{\circ} \mathrm{C}$ for $30 \mathrm{~s}$ and annealing at $55^{\circ} \mathrm{C}$ for $1 \mathrm{~min}$; and extension at $72^{\circ} \mathrm{C}$ for $30 \mathrm{~min} /$ cycle. $\mathrm{Im}-$ mediately after the final PCR cycle, a melt-curve analysis was performed to determine the specificity of the primers. The reaction was incubated at $95^{\circ} \mathrm{C}$ for $1 \mathrm{~min}$, annealed at $55^{\circ} \mathrm{C}$ for $30 \mathrm{~s}$, and then gradually increased to $95^{\circ} \mathrm{C}$ for $30 \mathrm{~s}$. Each reaction was run in triplicate. $\mathrm{qPCR}$ data were analyzed by the relative standard curve method as described previously (Adhikari et al. 2007). Gene expression in Kulm and Nec103 was expressed as fold changes relative to mock-inoculated tissue. Standard deviations were calculated to find differences $(P \leq$ $0.05)$ between fold changes in the ToxA-sensitive and -insensitive wheat cultivars. Correlation analysis between qPCR gene expression and GeneChip gene expression was performed to validate the results of this study, as described previously (Bolton et al. 2008). Nine genes analyzed by qPCR analysis were selected and used for comparison. $R^{2}$ and $r$ values were calculated from these data.

\section{Measurement of cell death using Evans blue.}

In separate experiments, the second leaves of 2-week-old seedlings of Kulm and Nec103 were infiltrated with ToxA and water. Leaf samples were collected at 4, 12, 24, and 48 hpi. To measure changes in absorbance values, leaf segments $(2.5 \mathrm{~cm}$ long) were excised (a total of 10 from two biological replicates) and placed in 2-ml centrifuge tubes. The leaf segments were submerged for $20 \mathrm{~min}$ in $1 \mathrm{ml}$ of Evans blue solution $(0.5 \%, \mathrm{wt} / \mathrm{vol})$ (MP Biomedicals, Solon, OH, U.S.A.) and homogenized using plastic pestles. Excess dye was removed with deionized water. The homogenates were centrifuged at $14,000 \times$

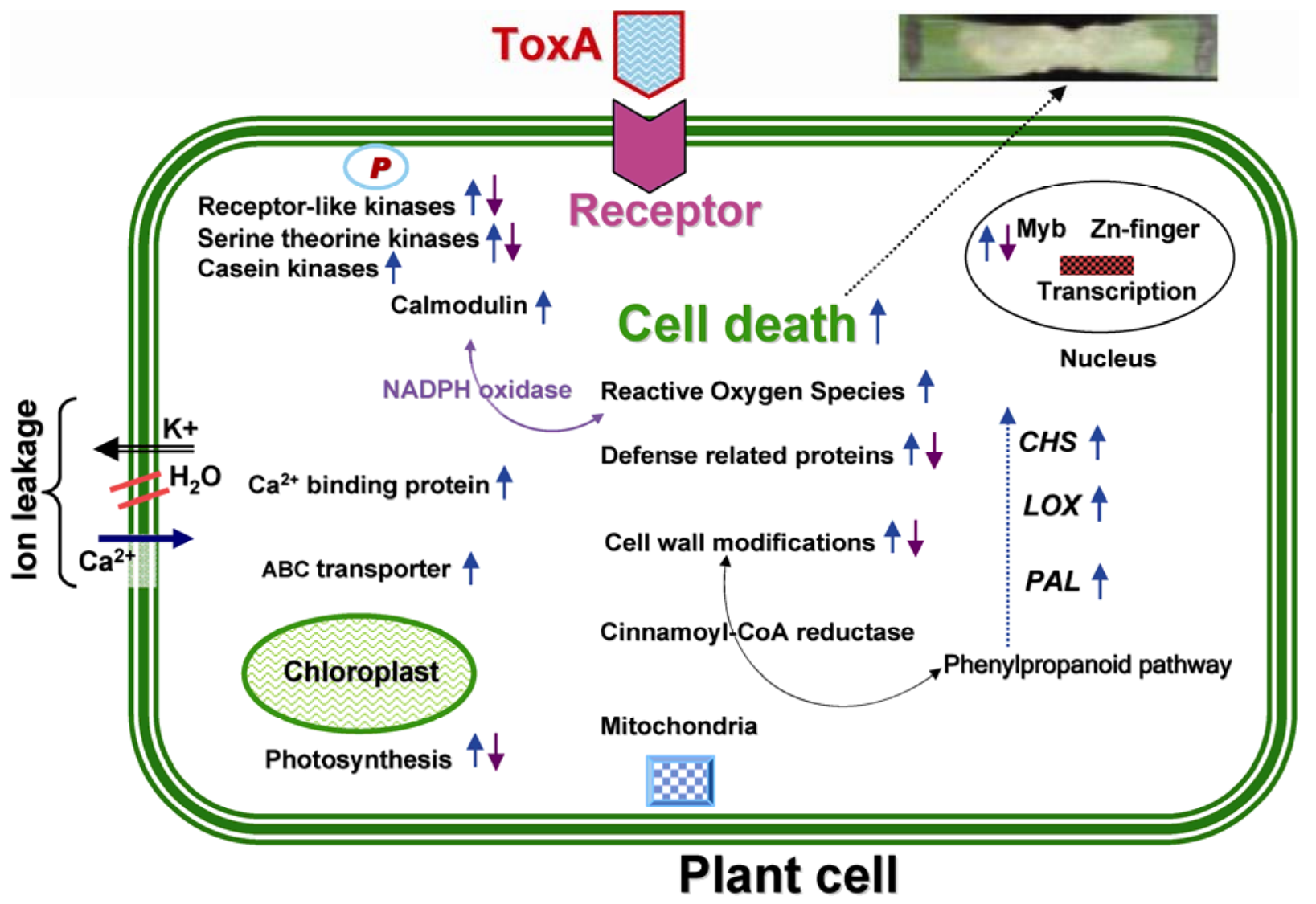

Fig. 8. Hypothetical model showing classes of genes and cellular processes altered during the susceptible response triggered by ToxA from Pyrenophora tritici-repentis. Blue arrows indicate upregulated genes ( $\geq$ twofold change, $P \leq 0.05$ ) and pink arrows represent downregulated genes from the different functional categories described in this investigation. Enzymes involved in the phenylpropanoid pathway include chalcone synthase (CHS), lipoxygenase (LOX), and phenylalanine ammonia lyase $(P A L)$. 
$g$ for $5 \mathrm{~min}$, transferred to $1 \%$ (wt/vol) sodium dodecyl sulfate, and incubated for $10 \mathrm{~min}$ at $37^{\circ} \mathrm{C}$. The absorbance values of dye in the supernatant were quantified by spectrophotometry (Thermo Electron Corp., Vantaa, Finland) at $600 \mathrm{~nm}$. Water was used as a control. To measure cell death, leaf sections $(2.5$ $\mathrm{cm}$ long) were excised (a total of 10 from two biological replicates), prepared without homogenization, and stained with Evans blue solution as described above. The leaf segments were examined using a Nikon Sclipse-E600 stereo microscope (Fryer Company, Inc., Bloomington, MN, U.S.A.). Dark blue staining of cells indicated cell death. The percentages of cell death values (scale of 0 to $100 \%$ ) were recorded (Baker and Mock 1994), and relative cell death values were calculated and level of significance was determined at $P<0.01$.

\section{Detection of $\mathrm{H}_{2} \mathrm{O}_{2}$ using DAB.}

The second leaves of 2-week-old seedlings of Kulm and Nec103 were infiltrated with ToxA or water (control). Leaf samples were collected at 4, 12, 24, and $48 \mathrm{~h}$ hpi. Approximately $2.5-\mathrm{cm}$ segments (a total of 10 from two biological replicates) from each treatment were stained using the DAB Liquid Substrate System (Sigma-Aldrich, Inc., St. Louis) as described by the manufacturer. Tissues were destained by boiling them in $90 \%$ ethanol alcohol for $5 \mathrm{~min}$ and rinsing in 50\% ethanol, then examined for the presence of a reddish-brown stain using a stereomicroscope equipped with a digital camera (Lecia Microsystems Heidelberg GmbH, Mannheim, Germany). Photographs were taken for each treatment.

\section{ACKNOWLEDGMENTS}

We thank N. Wang for analyzing the microarray data, Melvin Bolton for correlation analysis between the microarray data and qPCR data, and Scott Payne for photography. This work was supported in part by the National Research Initiative of the United States Department of AgricultureCooperative State Research Education and Extension Service (06-3531917442), the North Dakota-National Science Foundation program to stimulate competitive research (grant 044-7679, ND-NSF EPSCoR), and the North Dakota State University Agricultural Experiment Station.

\section{LITERATURE CITED}

Abramovitch, R. B., Anderson, J. C., and Martin, G. B. 2006. Bacterial elicitation and evasion of plant innate immunity. Nat. Rev. Mol. Cell Biol. 7:601-611.

Adhikari, T. B., Balaji, B., Cavaletto, J. R., and Goodwin, S. B. 2007. Analysis of genes expressed during wheat-Mycosphaerella graminicola interactions. Physiol. Mol. Plant Pathol. 71:55-68.

Adhikari, T. B., Ali, S., Myrfield, M., and Burlakoti, R. R. 2008. The global genetic structure of Pyrenophora tritici-repentis populations. (Abstr.) Phytopathology 98:S10.

Anderson, J. A., Effertz, R. J., and Faris, J. D., Francl, L. J., Meinhardt, S. W., and Gill, B. S. 1999. Genetic analysis of sensitivity to a Pyrenophora tritici-repentis necrosis-inducing toxin in durum and common wheat. Phytopathology 89:293-297.

Baker, C. J., and Mock, N. M. 1994. An improved method for monitoring cell death in cell suspension and leaf disc assay using Evans blue. Plant Cell Tissue Organ Cult. 39:1-12.

Balaji, V., Mayrose, M., Sherf, O., Jacob-Hirsch, J., Eichenlaub, R., Iraki, N., Manulis-Sasson, S., Rechavi, G., Barash, I., and Sessa, G. 2008. Tomato transcriptional changes in response to Clavibacter michiganensis subsp. michiganensis reveal a role for ethylene in disease development. Plant Physiol. 46:1797-1809.

Ballance, G. M., Lamari, L., Kowatsch, R., and Bernier, C.C. 1996. Cloning, expression and occurrence of the gene encoding the Ptr necrosis toxin from Pyrenophora tritici-repentis. Mol. Plant Pathol. 1996/1209ballance. Published online.

Bolton, M. D., Kolmer, J. A., Xu, W. W., and Garvin, D. F. 2008. Lr-34 mediated leaf rust resistance in wheat: Transcript profiling reveals a high energetic supported by transient recruitment of multiple metabolic pathways. Mol. Plant-Microbe Interact. 21:1515-1527.

Bradley, D. Kjellbom, P., and Lamb, C. 1992. Elicitor- and wound-induced oxidative cross-linking of a proline-rich plant cell wall protein: A novel, rapid defense response. Cell 70:21-30.

Brisson, L. F., Tenhaken, R., and Lamb, C. 1994. Function of cross-linking of cell wall structural proteins in plant disease resistance. Plant Cell 6:1703-1712.

Ciuffetti, L. M., and Tuori, R. P. 1999. Advances in the characterization of the Pyrenophora tritici-repentis-wheat interaction. Phytopathology 89:444-449.

Ciuffetti, L. M., Tuori, R. P., and Gaventa, J. M. 1997. A single gene encodes a selective toxin causal to the development of tan spot of wheat. Plant Cell 9:135-144.

Ciuffetti, L. M., Francl, L. J., Ballance, G. M., Bockus, W. W., Lamari, L., Meinhardt, S. W., and Rasmussen, J. B. 1998. Standardization of toxin nomenclature in the Pyrenophora tritici-repentis/wheat interaction. Can. J. Plant Pathol. 20:421-424.

Coram, T., Wang, M., and Chen, X. 2007. Transcriptome analysis of the wheat-Puccinia striiformis f. sp. tritici interaction. Mol. Plant Pathol. 9:157-169.

Desikan, R., S. A.-H.-Mackerness, Hancock, J. T., and Neill, S. J. 2001. Regulation of the Arabidopsis transcriptome by oxidative stress. Plant Physiol. 127:159-172.

Dowd, C., Wilson, I. W., and McFadden, H. 2004. Gene expression profile changes in cotton root and hypocotyl tissues in response to infection with Fusarium oxysporum f. sp. vasinfectum. Mol. Plant-Microbe Interact. 17:654-667.

Effertz, R. J., Meinhardt, S. W., Anderson, J. A., Jordahl, J. G., and Francl, L. J. 2002. Identification of a chlorosis-inducing toxin from Pyrenophora tritici-repentis and the chromosomal location of an insensitivity locus in wheat. Phytopathology 92:527-533.

Eulgem, T. 2005. Regulation of the Arabidopsis defense transcriptome. Trends Plant Sci. 10:70-78.

Faris, J. D., Anderson, J. A., Francl, L. J., and Jordahl, J. G. 1996. Chromosomal location of a gene conditioning insensitivity in wheat to a necrosis-inducing culture filtrate from Pyrenophora tritici-repentis. Phytopathology 86:459-463.

Faris, J. D., Li, W. L., Liu, D. J., Chen, P. D., and Gill, B. S. 1999. Candidate gene analysis of quantitative disease resistance in wheat. Theor. Appl. Genet. 98:219-225.

Faris, J. D., Lu, H. J., Zhang, Z., Reddy, L., Lui, Z. H., Xu, S. S., Chu, C. G., Abeysekara, N., Fellers, J. P., Cloutier, S., Keller, B., Scofield, S. R., and Friesen, T. L. 2008. Genetics of host-pathogen interactions in the wheat-Stagonospora nodorum pathosystem. In: Proc. 11th Int. Wheat Genetics Symp. R. Appels, R. Eastwood, E. Lagudah, P. Langridge, M. Mackay, L. McIntyre, and P. Sharp, eds. Sydney University Press, Sydney, Australia. Published online.

Flor, H. H., 1971. Current status of the gene-for-gene concept. Annu. Rev. Phytopathol. 9:275-296.

Freeman, T., Rasmussen, J. B., Francl, L. J., and Meinhardt, S. W. 1995 Wheat necrosis induced by Pyrenophora tritici-repentis toxin. Pages 990-991 in: Proc. Microsc. Microanal. G. W. Bailey, M. H. Ellisman, R. Hennigar, and N. J. Zaluzec, eds. Jones and Begell, New York.

Friesen, T. L., Rasmussen, J. B., Ali, S., Kwon, C. Y., Francl, L. J., and Meinhardt, S. W. 2002. Reaction to Pyrenophora tritici-repentis race 1 by wheat mutants insensitive to Ptr ToxA. Phytopathology 92:3842.

Friesen, T. L., Ali, S., Kianian, S., Francl, L. J., and Rasmussen, J. B. 2003. Role of host sensitivity to Ptr ToxA in development of tan spot of wheat. Phytopathology 93:397-401.

Friesen, T. L., Stukenbrock, E. H., Liu, Z. H., Meinhardt, S., Ling H., Faris, J. D., Rasmussen, J. B., Solomon, P. S., McDonald, B. A., and Oliver, R. P. 2006. Emergence of a new disease as a result of interspecific virulence gene transfer. Nat. Genet. 38:953-956.

Gomez, K. A., and Gomez, A. A. 1984. Statistical Procedures for Agricultural Research, 2nd ed. John Wiley and Sons, New York.

Hahlbrock, K., and Scheel, D. 1989. Physiology and molecular biology of phenylpropanoid metabolism. Annu. Rev. Plant Physiol. Plant Mol. Biol. 40:347-369.

Hammond-Kosack, K. E., and Jones, J. D. G. 1996. Resistance genedependent plant defense responses. Plant Cell 8:1773-1791.

Hulbert, S. H., Bai, J., Fellers, J. P., Pacheco, M. G., and Bowden, R. L. 2007. Gene expression patterns in near isogenic lines for wheat rust resistance gene Lr34/Yr18. Phytopathology 97:1083-1093.

Joosten, M. H. A. J., and De Wit, P. J. D. M. 1989. Identification of several pathogenesis-related proteins in tomato leaves inoculated with Cladosporium fulvum as 1,3- $\beta$-glucanases and chitinases. Plant Physiol. 89:945-961.

Keon, J., Antoniw, J., Carzaniga, R., Deller, S., Ward, J. L., Baker, J. M., Beale, M. H., Hammond-Kosack, K. E., and Rudd, J. J. 2007. Transcriptional adaptation of Mycosphaerella graminicola to programmed cell death of its susceptible wheat host. Mol Plant-Microbe Interact 20:178-193. 
Kwon, C. Y., Rasmussen, J. B., and Meinhardt, S. W. 1998. Activity of Ptr ToxA from Pyrenophora tritici-repentis requires host metabolism. Physiol. Mol. Plant Pathol. 52:201-212.

La Camera, S. Gouzerh, G., Dhondt, S., Hoffmann, L., Fritig, B., Legrand, M., and Heit, T. 2004. Metabolic reprogramming in plant innate immunity: The contributions of phenylpropanoid and oxylipin pathways. Immunol. Rev. 198:267-284.

Lamari, L., and Bernier, C. C. 1989. Toxin of Pyrenophora tritici-repentis: Host-specificity, significance in disease, and inheritance of host reaction. Phytopathology 79:740-744.

Lamari, L., Strelkov, S. E., Yahyaoui, A., Orabi, J., and Smith, R. B. 2002. The identification of two new races of Pyrenophora tritici-repentis from the host center of diversity confirms a one-to-one relationship in tan spot of wheat. Phytopathology 93:391-396.

Lamb, C., and Dixon, R. A. 1997. The oxidative burst in plant disease resistance. Annu. Rev. Plant Physiol. Plant Mol. Biol. 48:251-275.

Levine, A., Tenhaken, R., Dixon, R., and Lamb, C. 1994. $\mathrm{H}_{2} \mathrm{O}_{2}$ from the oxidative burst orchestrates the plant hypersensitive disease resistance response. Cell 79:583-593.

Liu, B., Zhang, S., Zhu, X., Yang, Q. Wu, S., Mei, M., Mauleon, R., Leach J., Mew, T., and Leung, H. 2004. Candidate defense genes as predictors of quantitative blast resistance in rice. Mol. Plant-Microbe Interact. 17:1146-1152.

Manning, V. A., and Ciuffetti, L. M. 2005. Localization of Ptr ToxA produced by Pyrenophora tritici-repentis reveals protein import into wheat mesophyll cells. Plant Cell 17:3203-3212.

Manning, V. A., and Ciuffetti, L. M. 2007. Ptr ToxA interacts with a chloroplast-localized protein. Mol. Plant-Microbe Interact. 20:168-177.

Manning, V. A., Andrie, R. M., Trippe, A. F., and Ciuffetti, L. M. 2004. Ptr ToxA requires multiple motifs for complete activity. Mol. PlantMicrobe Interact. 17:491-501.

Manning, V. A., Hamilton, S. M., Karplus, P. A., and Ciuffetti, L. M. 2008. The Arg-Gly-Asp-containing, solvent-exposed loop of Ptr ToxA is required for internalization. Mol. Plant-Microbe Interact. 21:315325

Manning, V. A., Chu, A., Steeves, J. E., Wolpert, T. J., and Ciuffetti, L. M. 2009. A host-selective toxin of Pyrenophora tritici-repentis, Ptr ToxA induces photosystem changes and reactive oxygen species accumulation in sensitive wheat. Mol. Plant-Microbe Interact. 22:665-676.

Martin, G. B., Bogdanove, A. J., and Sessa, G. 2003. Understanding the functions of plant disease resistance proteins. Annu. Rev. Plant Biol. 54:23-61.

Meinhardt, S. W., Cheng, W., Kwon, C. Y., Donohue, C. M., and Rasmussen, J. B. 2002. Role of the arginyl-glycyl-aspartic motif in the action of Ptr ToxA produced by Pyrenophora tritici-repentis. Plant Physiol. 130:1545-1551.

Moy, P., Qutob, D., Chapman, B. P., Atkinson, I., and Gijzen, M. 2004 Patterns of gene expression upon infection of soybean plants by Phytophthora sojae. Mol. Plant-Microbe Interact. 17:1051-1062.

Rasmussen, J. B., Kwon, C. Y., and Meinhardt, S. W. 2004. Requirement of host signaling mechanisms for the action of Ptr ToxA in wheat. Eur. J. Plant Pathol.110:333-335.

Restrepo, S., Myers, K. L., del Pozo, O., Martin, G. B., Hart, A. L., Buell, C. R. Fry, W. E., and. Smart, C. D. 2005. Gene profiling of a compatible interaction between Phytophthora infestans and Solanum tuberosum suggests a role for carbonic anhydrase. Mol. Plant-Microbe Interact. 18:913-922

Rudd, J. J., Keon, J., and Hammond-Kosack, K. E. 2008. The wheat mitogen-activated protein kinases TaMPK3 and TaMPK6 are differentially regulated at multiple levels during compatible disease interactions with Mycosphaerella graminicola. Plant Physiol. 147:802-815.

Sarma, G. N., Manning, V. M., Ciuffetti, L. M., and Karplus, P. A. 2005. Structure of Ptr ToxA: An RGD-containing host-selective toxin from Pyrenophora tritici-repentis. Plant Cell 17:3190-3202.

Shimizu, T., Satoh, K., Kikuchi, S., and Omura, T. 2007. The repression of cell wall- and plastid-related genes and the induction of defense-related genes in rice plants infected with rice dwarf virus. Mol. Plant-Microbe Interact. 20:247-254.

Strelkov, S. E., and Lamari, L. 2003. Host-parasite interaction in tan spot Pyrenophora tritici-repentis of wheat. Can. J. Plant Pathol. 25:339-349.

Strelkov, S. E., Lamari, L., and Ballance, G. M. 1999. Characterization of a host-specific protein toxin (Ptr ToxB) from Pyrenophora tritici-repentis. Mol. Plant-Microbe Interact. 12:728-732.

Suzuki, S., Oldberg, A., Hayman, E. G., Pierschbacher, M. D., and Rouslahti, E. 1985. Complete amino acid sequence of human vitronectin and fibronectin. EMBO (Eur. Mol. Biol. Organ.) J. 4:2519-2524.

Thilmony, R., Underwood, W., and He, S. Y. 2006. Genome-wide transcriptional analysis of the Arabidopsis thaliana interaction with the plant pathogen Pseudomonas syringae pv. tomato DC3000 and the human pathogen Escherichia coli 0157:H7. Plant J. 46:34-53.

Thordal-Christensen, H. Zhang, Z., Wei, Y., and Collinge, D. B. 1997. Subcellular localization of $\mathrm{H}_{2} \mathrm{O}_{2}$ in plants. $\mathrm{H}_{2} \mathrm{O}_{2}$ accumulation in papillae and hypersensitive response during the barley-powdery mildew interaction. Plant J. 11:1187-1194.

Tomás, A., Feng, G. H., Reeck, G. R., Bockus, W. W., and Leach, J. E. 1990. Purification of a cultivar-specific toxin from Pyrenophora triticirepentis, causal agent of tan spot of wheat. Mol. Plant-Microbe Interact. 8:41-48.

Tuori, R. P., Wolpert, T. J., and Ciuffetti, L. M. 1995. Purification and immunological characterization of toxic components from cultures of Pyrenophora tritici-repentis. Mol. Plant-Microbe Interact. 8:41-48.

Venisse, J. S., Malnoy, M., Faize, M. Paulin, J. P., and Brisset, M. N. 2002. Modulation of defense responses of Malus spp. during the compatible and incompatible interactions with Erwinia amylovora. Mol. PlantMicrobe Interact. 15:1204-1212.

Wolpert, T. J., Dunkle, L. D., and Ciuffetti, L. M. 2002. Host-selective toxins and avirulence determinants: What's in a name? Annu. Rev. Phytopathol. 40:251-285.

Zabala, G., Zou, J., Tuteja, J., Gonzalez, D. O., Clough, S. J., and Vodkin, L. O. 2006. Transcriptome changes in the phenylpropanoid pathway of Glycine max in response to Pseudomonas syringae infection. BMC Plant Biol. 6:26.

Zhang, H.-F., Francl, L. J., Jordahl, J. G., and Meinhardt, S. W. 1997. Structural and physical properties of a necrosis-inducing toxin from Pyrenophora tritici-repentis. Phytopathology 87:154-160.

\section{AUTHOR-RECOMMENDED INTERNET RESOURCE}

MIPS Arabidopsis thaliana database:http://mips.gsf.de/proj/thal/db 